\title{
p166 links membrane and intramitochondrial modules of the trypanosomal tripartite attachment complex
}

Bernd Schimanski ${ }^{*}$, Salome Aeschlimann ${ }^{1,2}$, Sandro Käser ${ }^{1}$, Maria Gomez-Fabra Gala ${ }^{3,4,5}$, Nora Vögtle ${ }^{3,6,7}$ and André Schneider ${ }^{1^{*}}$

${ }^{1}$ Department of Chemistry, Biochemistry and Pharmaceutical Sciences, University of Bern, Freiestrasse 3, Bern CH-3012, Switzerland

${ }^{2}$ Graduate School for Cellular and Biomedical Sciences, University of Bern, Bern, Switzerland ${ }^{3}$ Institute of Biochemistry and Molecular Biology, ZBMZ, Faculty of Medicine, University of Freiburg, 79104 Freiburg, Germany

${ }^{4}$ Faculty of Biology, University of Freiburg, 79104 Freiburg, Germany

${ }^{5}$ Spemann Graduate School of Biology and Medicine, University of Freiburg, 79104 Freiburg, Germany

${ }^{6}$ CIBSS - Centre for Integrative Biological Signalling Studies, University of Freiburg, 79104 Freiburg, Germany

${ }^{7}$ present address: Center for Molecular Biology of Heidelberg University (ZMBH), DKFZ-ZMBH Alliance and Network Aging Research, University of Heidelberg, 69120 Heidelberg, Germany

*corresponding authors: bernd.schimanski@unibe.ch, andre.schneider@unibe.ch

Short title: $\mathrm{p} 166$ the integral inner membrane TAC subunit 
bioRxiv preprint doi: https://doi.org/10.1101/2021.12.16.473092; this version posted December 17, 2021. The copyright holder for this preprint (which was not certified by peer review) is the author/funder, who has granted bioRxiv a license to display the preprint in perpetuity. It is made available under aCC-BY 4.0 International license.

\section{ABSTRACT}

The protist parasite Trypanosoma brucei has a single mitochondrion with a single unit genome termed kinetoplast DNA (kDNA). Faithfull segregation of replicated kDNA is ensured by a complicated structure termed tripartite attachment complex (TAC). The TAC physically links the basal body of the flagellum with the kDNA spanning the two mitochondrial membranes. Here, we characterized p166 as the only TAC subunit that is anchored in the inner membrane. Its C-terminal transmembrane domain separates the protein into a large $\mathrm{N}$-terminal region that interacts with the kDNA-localized TAC102 and a 34 aa C-tail that binds to the intermembrane space-exposed loop of the integral outer membrane protein TAC60. Thus, in contrast to the outer membrane TAC region which requires four essential subunits for proper function a single inner membrane TAC subunit is sufficient to bridge the distance from the OM to the kDNA. Surprisingly, non-functional p166 lacking the C-terminal 34 aa still localizes to the TAC region. This suggests the existence of nonessential TAC-associated proteins in the OM. These proteins can loosely bind to non-functional p166 lacking the C-terminal 34 aa and keep it at the TAC but their binding would not be strong enough to withstand the mechanical force upon kDNA segregation.

\section{AUTHOR SUMMARY}

Mitochondria evolved from a single endosymbiotic event and are a hallmark of eukaryotes. The large majority of genes for mitochondrial proteins are nuclear encoded now and only a small number are found in the mitochondrial genome. The protist Trypanosoma brucei is an extreme eukaryote in many aspects. For instance, trypanosomes have a single mitochondrion and its genome - called kinetoplast DNA (kDNA) - locates as a single unit inside the mitochondrion close to the basal body of the flagellum. The tripartite attachment complex (TAC) forms a connection between the basal body and the kDNA ensuring faithful segregation of kDNA among the daughter cells upon cytokinesis. Recently, several TAC subunits of the cytoplasm, the outer mitochondrial membrane (OM) and the mitochondrial matrix have been characterized. Here, we identify p166 as the first TAC subunit of the inner mitochondrial membrane. It is anchored with a single transmembrane domain separating the protein into a N-terminal moiety located in the matrix and a short C-tail. The latter reaches into the intermembrane space and binds the OM subunit TAC60 whereas the $\mathrm{N}$-terminus interacts with the matrix subunit TAC102. Thus, with $\mathrm{p} 166$ we identified the missing link required to connect different modules of the TAC. 
bioRxiv preprint doi: https://doi.org/10.1101/2021.12.16.473092; this version posted December 17, 2021. The copyright holder for this preprint (which was not certified by peer review) is the author/funder, who has granted bioRxiv a license to display the preprint in perpetuity. It is made available under aCC-BY 4.0 International license.

\section{INTRODUCTION}

Mitochondria have an own genome which reflects their bacterial ancestry. Moreover, even though most mitochondrial proteins are imported from the cytosol, the few organellar-encoded proteins are essential for mitochondrial function (1-3). Eukaryotes therefore require mechanisms to guarantee that the mitochondria and their genomes are faithfully divided and segregated to the daughter cells during cell division (4-6). The parasitic protozoon Trypanosoma brucei is an extreme example for this. Unlike yeast and mammals, which have numerous mitochondria each having multiple genomes, it has only a single mitochondrion with a single unit genome, termed kinetoplast DNA ( $k D N A)$, that is localized to a specific region within the organelle $(7,8)$. The kDNA consists of two highly intercalated populations of circular DNA molecules that form a disc-like structure composed of a few dozens of maxicircles (22 kb in length) and a few thousand of minicircles (1 kb in length) $(9,10)$. Maxicircles are functionally analogous to the mitochondrial genome of other species. They encode 18 protein-coding genes many of which are cryptogenes, meaning their transcripts need to be extensively edited to convert them into functional mRNAs. The minicircles are heterogenous in sequence and encode guide RNAs serving as templates to mediate RNA editing (11-13). Unlike suggested for yeast and mammals whose mitochondrial genomes are distributed within the organelle, stochastic partition cannot be the mechanism to segregate the old and the newly replicated kDNAs to the daughter cells. Instead, trypanosomes have a hardwired structure, termed tripartite attachment complex (TAC), that connects the matrix located kDNA disc across the two mitochondrial membranes with the basal body of the flagellum and thus couples segregation of the replicated kDNA to the segregation of the old and the new flagellum in dividing cells $(10,14)$. The TAC is restricted to kinetoplastids. However, a recent study suggests that the concept of coupling inheritance of organelles to flagellar segregation also applies to mitosomes of the anaerobic protist Giardia. In these cells a subgroup of mitosomes is linked to axonemes of the oldest flagella (15, 16) raising the question whether this arrangement is an ancestral or a derived trait.

Segregation of the trypanosomal kDNA works as follows. During replication of the kDNA, which is tightly coordinated with cell cycle and occurs shortly before the onset of the S-phase, the kDNA network doubles in size $(7,8)$. Subsequently a new TAC is formed that links the new basal body to the replicated kDNA disc. Finally, segregation of the old and the new flagellum will separate the old and the new kDNA networks, before the mitochondrion is divided in two between the pair of basal bodies and the kDNA discs during cytokinesis (17).

The TAC can be divided into three morphologically defined regions: (i) the exclusion zone filaments (EZF) that connect the basal body to the mitochondrial outer membrane (OM); (ii) the differentiated membranes (DM) where OM and inner membrane (IM) are closely opposed and (iii) the unilateral filaments (ULF) inside mitochondria which connect the IM to the kDNA disc (18). In their pioneering study Zhao et al. discovered the first TAC subunit, named p166, by screening an 
bioRxiv preprint doi: https://doi.org/10.1101/2021.12.16.473092; this version posted December 17, 2021. The copyright holder for this preprint (which was not certified by peer review) is the author/funder, who has granted bioRxiv a license to display the preprint in perpetuity. It is made available under aCC-BY 4.0 International license.

4

RNAi library for kDNA loss (19). Since then seven further essential TAC subunits have been characterized that are localized to all three TAC regions (14).

TAC assembly is a complex problem. It has been shown that the three TAC regions are formed in a hierarchical and temporally controlled way, starting at the basal body with the EZF, which after their formation connect to the TAC subunits in the DM region (20). Finally, the ULF are formed which link the IM to the newly replicated KDNA disc. TAC biogenesis therefore requires the coordinated assembly of a cytosolic module (EZF), a module consisting of integral mitochondrial OM and IM proteins (DM) and an intramitochondrial module (ULF) (20). The DM module is of special interest because it links the extramitochondrial EZF tether with the intramitochondrial ULF tether. The OM part of this module is amazingly complex. It consists of four essential integral membrane TAC subunits: the beta-barrel proteins TAC40 (21) and TAC42, TAC60 (22), and pATOM36 (23), which besides being a TAC subunit is also involved in the biogenesis of OM proteins $(23,24)$. All of these subunits are inserted into the OM with the help of the atypical protein translocase of OM (ATOM) that is localized all over the surface of the mitochondrion (25). After membrane insertion the OM TAC subunits are transported to the small very defined region of the DM between the basal body and the kDNA, in what is arguably the most extreme lateral sorting event known for any mitochondrion. In contrast to the OM not a single integral membrane TAC subunit has been identified in the IM. p166 would be an interesting candidate for an IM TAC subunit, as it contains a predicted N-terminal mitochondrial targeting sequence (MTS) and a transmembrane domain (TMD) near its C-terminus. However, a variant of p166 which lacks the TMD still correctly localized to the TAC, indicating that its localization does not depend on the TMD (19).

Here we have investigated the function and the biogenesis of $p 166$. We show that the protein is indeed the missing integral IM TAC subunit. Furthermore, we demonstrate that its C-terminus is oriented towards the intermembrane space (IMS) where it interacts with the IMS-exposed loop of the OM TAC subunit TAC60. Finally, our data indicate that assembly of p166 into the TAC is a twostep process involving low affinity interactions with so far unknown TAC-associated proteins and a high affinity with OM TAC subunits to stably lock it in the growing TAC structure.

\section{RESULTS}

\section{p166 is an essential TAC component of the mitochondrial IM}

In a first step to characterize p166 we established a cell line capable of RNAi-mediated downregulation using the 3' UTR of the p166 mRNA as target (Fig. 1A, left panel). Knockdown of p166 leads to a growth retardation around 3 days after induction of RNAi. A quantitative analysis of kDNAs by fluorescent microscopy 2 days after induction of RNAi revealed a remarkable loss of the mitochondrial genome in more than $75 \%$ of cells. As a hallmark of failed kDNA segregation cells 
bioRxiv preprint doi: https://doi.org/10.1101/2021.12.16.473092; this version posted December 17, 2021. The copyright holder for this preprint (which was not certified by peer review) is the author/funder, who has granted bioRxiv a license to display the preprint in perpetuity. It is made available under aCC-BY 4.0 International license.

5

with smaller (15\%) and enlarged overreplicated kDNAs (6\%) could be observed (Fig. 1B, left panel). Overall, these data agree well with previous findings about p166 (19) and all other described TAC components (14). In a next step the RNAi cell line was further transfected with a construct leading to the integration of a C-terminal triple HA tag sequence in one allele of p166 resulting in the expression of an in situ epitope-tagged version of p166 (p166-HA, Fig. 2A). Importantly, the tagged gene acquired with the tubulin intergenic region a different $3^{\prime}$ UTR and is therefore resistant to RNAi and constitutively expressed in the absence or presence of wild-type p166 (Fig 1A, right panel). Analysis of cell growth indicates that the expression of in situ tagged p166-HA can fully complement for the loss of wild-type p166 upon RNAi (Fig 1A, right panel). Furthermore, no changes in kDNA levels can be observed in cells expressing both wild-type and tagged p166 and in cells exclusively expressing the tagged version (Fig 1B, right panel). Finally, the subcellular localization of the tagged p166 was investigated by immunofluorescence microscopy using uninduced whole cells as samples (Fig. 1C). The result shows that p166-HA localizes between the basal body of the flagellum and the kDNA which is in line with previous findings (19). We therefore conclude that tagged p166 is correctly localized, that the tag does not interfere with $\mathrm{p} 166$ function and that all further results using p166-HA are representative for wildtype $\mathrm{p} 166$ as well.

p166 consists of 1501 amino acids, contains a predicted MTS at the $\mathrm{N}$-terminus and a single predicted TMD close to the C-terminus (Fig. 2A). Biochemical analysis confirmed that p166 is indeed found in the mitochondria-enriched pellet after digitonin fractionation together with the mitochondrial OM protein ATOM40 and in contrast to the cytoplasmic protein EF1a. Furthermore, after alkaline carbonate extraction of mitochondria p166 is found in the pellet fraction together with ATOM40 indicating that p166 is an integral membrane protein (Fig. 2B) (26). To exclude that fractionation of p166 into the carbonate pellet is an artefact due to aggregation, the pellet was treated with Triton-X-100 which showed that, as expected for an integral membrane protein, $\mathrm{p} 166$ is solubilized (Fig. S1).

In a previous study the subcellular localization of known TAC components including p166 was analyzed and their distance to the basal body was measured (20). p166 was shown to be more distant to the basal body than the OM TAC components TAC60 and TAC40 and closer to the matrix subunit TAC102. This indicates that membrane integral p166 is located in the IM of mitochondria. Furthermore, the predicted presence of a MTS indicates that p166 is indeed a IM protein. To test if the predicted MTS sequence is functioning as a mitochondrial import signal in vivo, trypanosomes were transfected with different constructs allowing for inducible expression of GFP. As shown in figure 2C GFP localizes to the cytoplasm. In contrast, GFP versions containing the previously characterized 15 amino acids long MTS of mitochondrial heat shock protein 60 (mtHSP60) or the first 25 amino acids of p166 at their N-termini are efficiently imported into the mitochondrion. Based on the mentioned previous observations and our new results we conclude that $\mathrm{p} 166$ is localized in the IM. 
bioRxiv preprint doi: https://doi.org/10.1101/2021.12.16.473092; this version posted December 17, 2021. The copyright holder for this preprint (which was not certified by peer review) is the author/funder, who has granted bioRxiv a license to display the preprint in perpetuity. It is made available under aCC-BY 4.0 International license.

\section{The C-tail of $\mathrm{p} 166$ is indispensable for function}

The previous study by Zhao et al. (19) indicated that the C-tail of p166 is not necessary for correct localization. However, these experiments were performed in cells expressing both wild-type and tagged C-terminally truncated p166 simultaneously. It was therefore not possible to determine if the $\mathrm{C}$-tail is needed for the proper function of $\mathrm{p} 166$. To address this question we modified one allele of p166 in the cell line capable of RNAi against the p166 3'UTR with a construct leading to the expression of a RNAi resistant in situ tagged version of p166 lacking the last $34 \mathrm{C}$-terminal amino acids (p166- $\Delta$ C-HA, Fig. 3A). Digitonin fractionation and alkaline carbonate extraction confirmed that p166- $\Delta \mathrm{C}-\mathrm{HA}$ still behaves like an integral mitochondrial membrane protein (Fig. 3B). However, cell growth analysis after RNAi-mediated ablation of wild-type p166 revealed that p166$\triangle \mathrm{C}-\mathrm{HA}$ is not able to complement for the loss of endogenous p166 (Fig. 3C). The observed growth phenotype is due to a pronounced kDNA segregation defect with the majority of cells losing their kDNA after 2 days of induction. Again and similar to downregulation of p166 alone (Fig 1B), more than $70 \%$ of the cells analyzed show no detectable kDNA whereas around $7 \%$ and $17 \%$ of the cells harbour small and enlarged kDNAs, respectively (Fig. 3D). These aberrant kDNAs and the localization of the tagged p166 variant can be visualized by immunofluorescene microscopy (Fig. $3 \mathrm{E}$, middle and right panel). The results show that the C-terminal truncated p166 is correctly localized between the basal bodies and the small and overreplicated kDNAs. Furthermore, even in cells which lack kDNA p166- $\triangle \mathrm{C}-\mathrm{HA}$ is still associated with the basal bodies, indicating that the correct localization of p166 is independent of the presence of kDNA (Fig. 3E, right panel).

\section{The C-tail of p166 reaches into the IMS}

The results presented so far strongly indicate that the C-terminus of p166 is essential for proper TAC function. In a next step we wanted to investigate the topology of $\mathrm{p} 166$. The fact that in the DM region of the TAC the OM and IM are closely opposed and therefore essentially exclude any IMS strongly suggests that the large soluble $150 \mathrm{kDa}$-terminal part of $\mathrm{p} 166$ is oriented towards the matrix side.

Full length variants of p166 that are firmly integrated into the TAC are insoluble and therefore difficult to study. Thus, we established two individual cell lines expressing mini-versions of $p 166$ that lack the N-terminal 1359 amino acids (mini-p166-HA) as well as in the second case the 34 amino acid C-tail distal to the TMD (mini-p166- $\Delta$ C-HA) (Fig. 4A). Since the deleted N-terminal domain of p166 also contains the MTS, the 15 amino acids long MTS of mtHSP60 was fused to the N-termini of both variants. As a result, the truncated fusion proteins are imported into the mitochondrion and can be found in the membrane fraction (Fig. S2). Next, the cell growth and kDNA segregation were monitored upon expression of the truncated proteins. A slight slow growth phenotype starting at day 4 after induction could be observed in cells expressing mini-p166-HA with an intact C-terminus (Fig. 4B, left panel). Moreover, analysis of the kDNA content after 2 days 
bioRxiv preprint doi: https://doi.org/10.1101/2021.12.16.473092; this version posted December 17, 2021. The copyright holder for this preprint (which was not certified by peer review) is the author/funder, who has granted bioRxiv a license to display the preprint in perpetuity. It is made available under aCC-BY 4.0 International license.

of induction revealed a striking decrease of cells containing normal kDNA and a simultaneous appearance of cells with small or overreplicated kDNAs. At day 8 after induction this effect was even more pronounced (Fig. 4C, left panel). In contrast, cells expressing mini-p166- $\Delta C-H A$, which lacks the C-terminus, do not show a growth phenotype and their kDNA content stayed virtually unchanged over the whole course of the experiment (Fig. 4BC, right panels).

When whole cells were analyzed by immunofluorescence microscopy, both mini-versions of p166 were found distributed all over the mitochondrial membrane. However, the signals are not evenly distributed and local foci of higher signal strength could be observed some of which appear to be in close vicinity to the kDNA in the case of mini-p166-HA (Fig. 4D). To better visualize a possible TAC localization we also analyzed Triton-X100 extracted cytoskeletons by immunofluorescence. Here, a clear colocalization of mini-p166-HA with basal bodies could be observed in more than $90 \%$ of the cells analyzed. In contrast, mini-p166- $\Delta \mathrm{C}-\mathrm{HA}$ colocalized with basal bodies in only $11 \%$ of the cells. (Fig. 4E). Finally, isolated flagella were also analyzed. Here, mini-p166-HA colocalizes with basal bodies in almost $50 \%$ of the flagella investigated, whereas less then $3 \%$ of flagella showed a signal for mini-p166- $\triangle$ C-HA (Fig. 4F).

We conclude that while both mini-versions are imported into mitochondria, only p166-HA is stably integrated into the growing TAC. p166- $\triangle \mathrm{C}-\mathrm{HA}$ on the other hand is mostly lost in isolated cytoskeleton and flagella possibly because its interaction with the TAC is Triton-X100 sensitive. Based on the findings that the TAC is assembled stepwise beginning from the basal body towards the kDNA and that addition of new TAC components needs the presence of stably integrated TAC components upstream (20) the presented results can best be explained in the following way: The C-tail of $p 166$ reaches into the IMS and connects $p 166$ to already integrated upstream TAC components resulting in a correct and stable TAC localization. Due to the polarized assembly of the TAC stable localization of mini-p166-HA with an intact C-terminus does not depend on the large matrix-exposed N-terminus of p166. Moreover, overexpression of mini-p166-HA likely is able to compete for localization with wild-type p166 and thus explains the slight dominant-negative effect on kDNA segregation and cell growth (Fig. 4B, left panel). These effects are not seen for mini-p166- $\triangle \mathrm{C}-\mathrm{HA}$.

\section{The C-tail connects $\mathrm{p} 166$ to the OM subunit TAC60}

Having established that the C-tail of p166 reaches into the IMS we wanted to directly test a putative interaction with well-studied OM TAC subunits, namely the beta-barrel proteins TAC40 and TAC42 as well as TAC60 which contains two TMDs (Fig. 5A) $(21,22)$. Since full length p166 that is integrated into the TAC is not soluble we had to use cells expressing the mini-versions of p166 which can be fully solubilized by digitonin for pull down experiments. To that end cell lines were generated allowing simultaneous inducible overexpression of the c-myc tagged OM TAC subunits (TAC40, TAC42 and TAC60) together with the 3xHA tagged mini versions of $\mathrm{p} 166$. After 2 days of induction mitochondria were enriched by digitonin extraction and proteins solubilized from 
bioRxiv preprint doi: https://doi.org/10.1101/2021.12.16.473092; this version posted December 17, 2021. The copyright holder for this preprint (which was not certified by peer review) is the author/funder, who has granted bioRxiv a license to display the preprint in perpetuity. It is made available under aCC-BY 4.0 International license.

8

the pellets were subjected to anti c-myc immunoprecipitation. All three bait proteins TAC40, TAC42 and TAC60 were found to pull down mini-p166-HA, with TAC60 showing the highest enrichment. Importantly, the interaction with TAC60 was abolished in the pull-down with mini-p166- $\triangle \mathrm{C}-\mathrm{HA}$ highlighting the functional relevance of the C-tail (Fig 5B). TAC40, TAC42 and TAC60 were previously shown to form a stable subcomplex (22). Hence, from our pulldown experiments with all three baits we cannot define which OM TAC subunit interacts directly with the C-tail of $\mathrm{p} 166$. However, based on its topology TAC60 is the most likely candidate. Previous mutational analyses revealed that its $\mathrm{C}$-terminus is dispensable for function whereas a truncation of both the $\mathrm{N}$ - and the C-terminus leads to a correctly localized but non-functional TAC60 (22). Fig. 5C shows that both minimal versions of TAC60 are able to pull down p166-HA indicating that the interaction is at least partially mediated by the IMS loop of TAC60.

All immunoprecipitation discussed above were done under native conditions which results in the isolation of heteroligomeric protein complexes. It is therefore difficult to show whether any two proteins of the complex interact directly with each other. In order to circumvent that problem we coexpressed c-myc tagged TAC60 2 C283 and mini-p166-HA in Saccharomyces cerevisiae.

Subsequently, yeast mitochondria were isolated, lysed and the soluble proteins were subjected to anti c-myc immunoprecipitation. The result shows that C-terminal truncated TAC60 efficiently pulls down mini-p166-HA but not yeast Tom40 (Fig. 5D). Since TAC60 and mini-p166-HA are trypanosomatid-specific proteins that do not have orthologues in yeast, we conclude that p166 interacts directly with the IMS exposed loop of TAC60 (aa positions 142 - 237) without the need of any trypanosomal IMS protein.

\section{Localization of $\mathrm{p} 166$ is independent of the presence of C-tail or kDNA}

The results presented so far indicate that the C-tail is necessary for integrating p166 into the TAC as it interacts with the IMS-exposed loop of the OM TAC subunit TAC60. In light of the current model of stepwise TAC assembly from the basal body towards the kDNA this raises the question how the non-functional p166- $\Delta \mathrm{C}-\mathrm{HA}$ is able to localize correctly without the possibility to interact with upstream TAC subunits (Fig. 3E). Cells presented in Figure 3 express full length p166- $\Delta$ C-HA after RNAi mediated downregulation of wild-type p166. It is well possible that this knockdown is not complete and remaining amounts of wild-type p166 facilitate the localization of p166- $\Delta$ C-HA by homotypic interactions. An alternative explanation is the existence of so far unknown stabilizing factors in the IM that are kept in place by upstream TAC components and that interact with regions of p166 outside the C-tail.

To investigate this in more detail we switched to bloodstream form T. brucei as study objects. In particular, we chose the engineered cell line $\gamma \mathrm{L} 262 \mathrm{P}$ which grows normally in the complete absence of kDNA (27). First, we knocked out one allele of $p 166$ by replacement of the coding sequence with the gene for hygromycin resistance. Second, constructs for expression of in situ tagged full length $\mathrm{p} 166-\mathrm{HA}$ or $\mathrm{p} 166-\Delta \mathrm{C}-\mathrm{HA}$ were integrated in the remaining allele. As a 
bioRxiv preprint doi: https://doi.org/10.1101/2021.12.16.473092; this version posted December 17, 2021. The copyright holder for this preprint (which was not certified by peer review) is the author/funder, who has granted bioRxiv a license to display the preprint in perpetuity. It is made available under aCC-BY 4.0 International license.

9

consequence, both cell lines exclusively express the respective versions of tagged p166 (Fig. 6A and S3). All four cell lines are viable and show no obvious difference in growth rates when cultured in identical standard conditions (Fig. 6B). kDNA analysis confirmed that in situ tagged full length p166 is functional with the vast majority of cells exclusively expressing p166-HA showing normal amounts of kDNA. In contrast all cells expressing only p166- $\triangle \mathrm{C}-\mathrm{HA}$ lost their mitochondrial genome (Fig 6C). This again confirms that the C-tail is essential for $\mathrm{p} 166$ function in TAC mediated kDNA segregation.

When cytoskeletons were analyzed by immunofluorescence microscopy we noticed that both versions of p166 still locate close to the basal body (Fig. 6D). This proves that non-functional p166$\triangle \mathrm{C}-\mathrm{HA}$ can still localize correctly to the region of the TAC in the complete absence of either kDNA or wildtype $\mathrm{p} 166$. Thus, $\mathrm{p} 166-\Delta \mathrm{C}-\mathrm{HA}$ can localize to the kDNA-basal body region without having a C-tail that mediates the connection to upstream TAC components of the OM.

\section{DISCUSSION}

p166 was identified as the first subunit of the TAC in a pioneering study of the Englund lab using an RNAi library approach to screen for proteins involved in kDNA maintenance. Zhao et al. provided convincing evidence for $\mathrm{p} 166$ functioning in kDNA segregation rather than replication. In line with this, immunofluorescence analysis revealed that $\mathrm{p} 166$ is located between the basal body and the kDNA (19) (Fig 1C). However, it remained unclear where exactly within the three TAC regions p166 needs to be placed. The predicted presence of a TMD suggested it to be a membrane protein. The present study now provides biochemical evidence that $p 166$ is indeed an integral membrane protein (Fig. 2B). Furthermore, we show that the N-terminal 25 aa of p166 function as a MTS. This together with microscopic analyses in previous studies (20) let us conclude that $\mathrm{p} 166$ is localized in the IM and thus the first integral IM TAC subunit that has been identified. Our results show that p166 is anchored in the IM via its single C-terminal TMD thereby exposing the short C-tail to the IMS and the large N-terminal moiety into the mitochondrial matrix. This suggested topology of p166 is supported in several ways: (i) the C-tail of p166 stably interacts with the IMS exposed loop of the OM subunit TAC60; (ii) this interaction is disrupted in mutant p166 lacking the C-tail (Fig. 5) and (iii) a yeast two hybrid screen in a recent study revealed that the matrix TAC subunit TAC102 interacts with the N-terminus of $p 166$ (28). We therefore propose that $\mathrm{p} 166$ provides a direct connection of the OM TAC module with the matrix-localized TAC module. More specifically p166 bridges the distance between TAC60 in the OM and TAC102 in close vicinity of the kDNA (29). Co-immunoprecipitation experiments in yeast expressing variants of TAC60 and p166 indicate that no additional - possibly IMS-located - trypanosomal factors are needed for this stable interaction. Figure 7A shows a model of the DM-ULF region of the TAC emphasizing the new results of the present study.

Our results also suggest that $\mathrm{p} 166$ is the only essential integral IM subunit of the TAC. This is surprising and contrasts to the OM where we find 4 different integral membrane proteins (TAC40, 
bioRxiv preprint doi: https://doi.org/10.1101/2021.12.16.473092; this version posted December 17, 2021. The copyright holder for this preprint (which was not certified by peer review) is the author/funder, who has granted bioRxiv a license to display the preprint in perpetuity. It is made available under aCC-BY 4.0 International license.

10

TAC42, TAC60 and pATOM36) all of which were shown to be essential for TAC function (21-23). Except for PATOM36 which has a second function in OM protein biogenesis (23), the phenotype of RNAi cell lines for the OM TAC subunits is essentially identical to what is observed for other TAC subunits such as p197 (30), p166 (19) and TAC102 (29). This indicates that the function of TAC40, TAC42 and TAC60 is limited to the TAC raising the question why the TAC needs 4 subunits in the OM whereas a single one seems to be sufficient in the IM. Presently we cannot answer this question. However, there are two main scenarios. It is possible that the multiple TAC subunits in the OM could, at least in principle, be replaced by a single subunit. The seemingly unnecessary complexity of OM TAC region could in such a case be explained by a ratchet type mechanism termed constructive neutral evolution (31-33). This evolutionary mechanism can increase the complexity of a structure without providing a selective advantage for the cell. Alternatively, having four OM TAC subunits may be the result of adaptive evolution. What this advantage for the cell might be is difficult to discern. Both the EZF on the outside as well as the ULF on the inside interact with the OM. It can therefore be speculated that the four OM TAC subunits, which includes two beta barrel proteins $(21,22)$, are required to form a highly defined platform in the OM that integrates the organization of the EZF with the organization of the ULF.

The orientation of $\mathrm{p} 166$ in the IM was determined by expression of mini-versions lacking a substantial part of the $\mathrm{N}$-terminus. In immunofluorescence analyses of whole cells these versions were found spread in the entire IM (Fig 4D). This suggests that they are imported all over the mitochondrion by the mitochondrial protein translocases of trypanosomes, ATOM and TIM, which are also localized all over the OM and IM respectively $(25,34)$. Subsequently $p 166$ moves laterally in the IM towards its final destination and docks on already localized TAC subunits. A mutant miniversion lacking the $\mathrm{C}$-tail cannot make this connection with OM located subunits and is - unlike the mini-version with a complete C-tail - not found concentrated in the TAC region highlighting again the functional importance of the $\mathrm{C}$-tail.

In contrast to these results, non-functional $\mathrm{p} 166-\Delta \mathrm{C}-\mathrm{HA}$ with a complete $\mathrm{N}$-terminal sequence does localize correctly in the absence of kDNA and a wild-type copy of p166 in both procyclic and bloodstream forms of the parasite (Fig. 3E and 6D). A possible explanation for this observation is the existence of so far not identified factors that are able to stabilize the interaction of OM subunits with $\mathrm{p} 166$ in regions that are absent in the mini-versions of $\mathrm{p} 166$. These putative TAC associated proteins would be able to keep full length p166 at the TAC region irrespective of the presence or absence of its C-tail. The interaction between the postulated TAC-associated proteins and p166 would most likely be of low affinity, sufficiently stable to keep p166- $\Delta \mathrm{C}$ at the TAC but not strong enough to withstand the mechanical force upon kDNA segregation which would explain the loss of kDNA in cells expressing C-terminally truncated p166. Our working model for such scenarios is presented in Fig. 7B. We suggest that such stabilizing factors would be integral IM proteins whose IMS-domains could interact with OM TAC subunits. Their matrix-exposed domains on the other 
hand would bind to the N-terminal domain of p166 possibly with the predicted leucine zipper and/or other coiled-coiled motifs (19).

The identification of $\mathrm{p} 166$ as the very first TAC subunit is more than a decade ago (19). Since then, intensive research activities led to the characterization of six TAC subunits meeting all criteria for TAC components and pATOM36 with another function in addition to kDNA segregation. These subunits reside in the cytoplasmic EZF (p197 and TAC65), the outer DM (pATOM36, TAC40, TAC42 and TAC60) and the ULF in the mitochondrial matrix (TAC102) (14). p166 localizes to the inner DM and extends into the ULF and therefore represents the so far missing component allowing us to define subunits in all different compartments covered by the TAC. Our data suggest the presence of auxiliary proteins needed for assembly and stability of this essential structure. Hence, their identification and functional characterization will have to be the next level of TAC research in trypanosomes. 
bioRxiv preprint doi: https://doi.org/10.1101/2021.12.16.473092; this version posted December 17, 2021. The copyright holder for this preprint (which was not certified by peer review) is the author/funder, who has granted bioRxiv a license to display the preprint in perpetuity. It is made available under aCC-BY 4.0 International license.

12

\section{MATERIAL AND METHODS}

\section{Transgenic cell lines}

All procyclic cell lines are derivatives of Trypanosoma brucei 29-13 (35) grown at $27^{\circ} \mathrm{C}$ in SDM-79 supplemented with $10 \%(\mathrm{v} / \mathrm{v})$ fetal calf serum (FCS).

For tetracycline-inducible RNAi of p166 (Tb927.11.3290) cells were stably transfected with a Notllinearized plasmid containing stem-loop sequences covering the 3' UTR positions 32 to 386 .

In situ 3xHA-tagging of p166 was done by stable transfection of PCR products amplified using plasmids of the pMOtag series (36) with primers defining the sites of homologous recombination leading to expression of tagged full length p166 or a version lacking the last 34 amino acids comprising the C-tail.

A plasmid for inducible expression of POMP10-GFP (37) was used to generate the transfection vectors for studying the MTS of p166. In brief, POMP10 was excised with HindIII and Agel and subsequently, the backbone was either re-ligated after Klenow treatment for expression of cytosolic GFP or filled with oligonucleotides hybridized to generate compatible ends encoding the MTS of either mtHSP60 or p166.

Genomic DNA of cells expressing in situ tagged p166 was prepared and used as template for the amplification of coding sequences of $\mathrm{N}$-terminal truncated versions of $\mathrm{p} 166$. To ensure mitochondrial targeting of the overexpressed proteins the forward primer contained the sequence coding for the mitochondrial targeting sequence (MFRCVVRFGAKDIRF) of the mitochondrial matrix protein HSP60. PCR products were ligated into a derivative of pLEW100. The final plasmids were linearized with Notl before stable transfection.

The same constructs were stably transfected into cells capable of overexpression of triple c-myc tagged TAC40, TAC42 and TAC60 $(21,22)$.

Stably transfected bloodstream form $T$. brucei derive from a mutant cell line capable of surviving in the absence of kDNA (27). These cells were cultured in HMI-9 containing $10 \%(\mathrm{v} / \mathrm{v})$ FCS at $37^{\circ} \mathrm{C}$ with $5 \% \mathrm{CO}_{2}$. A plasmid for knockout of $\mathrm{p} 166$ was generated as follows. The 5 ' flanking sequence of $\mathrm{p} 166$ comprising the nucleotide positions $-513 /-3$ relative to the coding sequence and the 3 ' flank consisting of $+4507 /+5021$ were amplified and ligated into $\mathrm{Xhol} / \mathrm{HindlII}$ and $\mathrm{BamHI} / \mathrm{Sacl}$ of pMOtag43M thereby flanking the hygromycin resistance gene. The resulting plasmid was digested with Xhol and Sacl before electroporation. The resulting cell line was then further transfected with the described constructs for in situ tagging of the remaining p166 allele.

For co-expression of trypanosomal proteins in Saccharomyces cerevisiae, yeast cells (YPH499; MATa, ade2-101, his3- $\Delta 200$, leu2- $\Delta 1$, ura3-52, trp1- $\Delta 63$, lys2-801) were transformed with a derivative of pESC-HIS containing the coding sequences of C-terminal c-myc tagged TAC60 C283 and mini-p166-HA ligated into Notl/Clal and BamHI/Xhol, respectively (38).

\section{Isolation of yeast mitochondria}


bioRxiv preprint doi: https://doi.org/10.1101/2021.12.16.473092; this version posted December 17, 2021. The copyright holder for this preprint (which was not certified by peer review) is the author/funder, who has granted bioRxiv a license to display the preprint in perpetuity. It is made available under aCC-BY 4.0 International license.

13

Yeast cells were grown in SM-His medium (selective minimal medium, $0.67 \%[\mathrm{w} / \mathrm{v}]$ yeast nitrogen base without amino acids, $0.2 \%[\mathrm{w} / \mathrm{v}] \mathrm{SC}$ amino acid mixture, $2 \%[\mathrm{w} / \mathrm{v}]$ glucose) at $30^{\circ} \mathrm{C}$. Cells were harvested by centrifugation and the yeast pellet was resuspended in YPGal medium (1\% [w/v] yeast extract, $2 \%[\mathrm{w} / \mathrm{v}]$ bacto peptone, $2 \%[\mathrm{w} / \mathrm{v}]$ galactose) and grown for 18 hours at $30^{\circ} \mathrm{C}$. Cells were harvested in logarithmic growth phase and mitochondria were isolated by differential centrifugation (39). Mitochondria were resuspended in SEM buffer (250 mM sucrose, 1 mM EDTA, 10 mM MOPS$\mathrm{KOH}, \mathrm{pH} 7.2$ ), aliquoted, snap-frozen in liquid nitrogen and stored at $-80^{\circ} \mathrm{C}$.

\section{Protein analysis}

Digitonin extraction was performed to analyze the subcellular localization of proteins. $5 \times 10^{7}$ cells were harvested, washed and resuspended in SoTE buffer $(20 \mathrm{mM}$ Tris $\mathrm{HCl} \mathrm{pH} \mathrm{7.5,} \mathrm{0.6} \mathrm{M} \mathrm{sorbitol,} 2$ $\mathrm{mM}$ EDTA). An equal volume of SoTE containing $0.03 \%(\mathrm{w} / \mathrm{v})$ digitonin was added for selective membrane permeabilization. After incubation on ice for $10 \mathrm{~min}$ the sample was centrifuged for $5 \mathrm{~min}$ at $6800 \mathrm{~g}$. Equal cell equivalents of whole cells, the supernatant containing cytoplasmic protein and the mitochondria-endriched pellet were analyzed by immunoblot.

For alkaline carbonate extraction, mitochondria were enriched using the described digitonin fractionation and further separated into soluble and integral membrane proteins by incubation in 100 $\mathrm{mM} \mathrm{Na}_{2} \mathrm{CO}_{3} \mathrm{pH} 11.2$ for $10 \mathrm{~min}$ on ice and a subsequent centrifugation for $10 \mathrm{~min}$ at $1000^{\prime} 000 \mathrm{~g}$. Samples of the supernatant (soluble proteins) and pellet (membrane proteins) were subjected to immunoblot analysis.

For co-immunoprecipitation $1 \times 10^{8}$ cells were used to generate a mitochondria-enriched pellet as described above. Mitochondria were solubilized by incubation in lysis buffer $(20 \mathrm{mM}$ Tris $\mathrm{HCl} \mathrm{pH} 7.4$, $100 \mathrm{mM} \mathrm{NaCl}, 0.1 \mathrm{mM}$ EDTA, 10\% glycerol) containing 1\% digitonin and a protease inhibitor cocktail (Roche Complete, EDTA free) at three times the recommended concentration. After 15 min on ice, the sample was centrifuged for $15 \mathrm{~min}$ at $21^{\prime} 000 \mathrm{~g}$. The soluble supernatant was incubated with antic myc resin (Sigma) for 1 hour at $4^{\circ} \mathrm{C}$. Afterwards, the flow-through was collected, beads were washed 3 times with lysis buffer containing $0.1 \%$ digitonin and proteins were eluted by boiling the beads in SDS-PAGE sample loading buffer lacking $\beta$-mercaptoethanol. Fractions of the input, the flow-through and the entire eluted sample were precipitated using methanol and chloroform, resuspended in loading buffer containing $\beta$-mercaptoethanol and subjected to immunoblot analysis. Co-immunoprecipitation of yeast expressed proteins was performed essentially in the same way using $250 \mu \mathrm{g}$ isolated mitochondria lysed in the identical buffer as mentioned above.

\section{Immunofluorescence microscopy}

For the analysis of proteins in whole cells, parasites were harvested, washed, resupended in PBS and allowed to settle on slides for $10 \mathrm{~min}$ (procyclic forms) or $30 \mathrm{~min}$ (bloodstream forms). Cells were fixed using $4 \%$ paraformaldehyde and permeabilized with $0.2 \%$ Triton X-100. 
bioRxiv preprint doi: https://doi.org/10.1101/2021.12.16.473092; this version posted December 17, 2021. The copyright holder for this preprint (which was not certified by peer review) is the author/funder, who has granted bioRxiv a license to display the preprint in perpetuity. It is made available under aCC-BY 4.0 International license.

\section{4}

For the analysis of cytoskeletons the order of procedures was reversed. Cells were first permeabilized for $1 \mathrm{~min}$ and subsequently fixed with paraformaldehyde.

Flagella were isolated as described by (40). In brief, EDTA was added to the cultures at a final concentration of $5 \mathrm{mM}$ before harvesting. Afterwards, cells were harvested by centrifugation, resuspended in extraction buffer $\left(10 \mathrm{mM} \mathrm{NaH}_{2} \mathrm{PO}_{4}, 150 \mathrm{mM} \mathrm{NaCl}, 1 \mathrm{mM} \mathrm{MgCl}_{2}, \mathrm{pH}\right.$ 7.2) containing $0.5 \%$ Triton $\mathrm{X}-100$ and incubated for $10 \mathrm{~min}$ on ice. After centrifugation and washing with extraction buffer cells were incubated in extraction buffer containing $1 \mathrm{mM} \mathrm{CaCl}_{2}$ and incubated for $30 \mathrm{~min}$ on ice. Extracted flagella were pelleted by a $10 \mathrm{~min}$ spin, washed twice with PBS, resuspended in PBS and finally allowed to settle on glass slides. After fixing with paraformaldehyde samples were treated similar to whole cells or cytoskeletons.

Pictures were aquired using a DMI6000B microscope equipped with a DFC360 FX monochrome camera and LAS X software (Leica Microsystems). Images were further analyzed using Fiji software.

\section{Antibodies}

All antibodies used in this study are described in detail (22).

\section{REFERENCES}

1. Friedman JR, Nunnari J. Mitochondrial form and function. Nature. 2014;505(7483):335-43.

2. Pfanner N, Warscheid B, Wiedemann N. Mitochondrial proteins: from biogenesis to functional networks. Nat Rev Mol Cell Biol. 2019;20(5):267-84.

3. Hansen KG, Herrmann JM. Transport of Proteins into Mitochondria. Protein J. 2019;38(3):330-42.

4. Gustafsson CM, Falkenberg M, Larsson NG. Maintenance and Expression of Mammalian Mitochondrial DNA. Annu Rev Biochem. 2016;85:133-60.

5. Westermann B. Mitochondrial inheritance in yeast. Biochim Biophys Acta. 2013.

6. Kraus F, Roy K, Pucadyil TJ, Ryan MT. Function and regulation of the divisome for mitochondrial fission. Nature. 2021;590(7844):57-66.

7. Tyler KM, Matthews KR, Gull K. Anisomorphic cell division by African trypanosomes. Protist. 2001;152:367-78.

8. Wheeler RJ, Gull K, Sunter JD. Coordination of the Cell Cycle in Trypanosomes. Annual review of microbiology. 2019;73:133-54.

9. Jensen RE, Englund PT. Network news: the replication of kinetoplast DNA. Annu Rev Microbiol. 2012;66:473-91.

10. Povelones ML. Beyond replication: division and segregation of mitochondrial DNA in kinetoplastids. Mol Biochem Parasitol. 2014.

11. Maslov DA. Separating the Wheat from the Chaff: RNA Editing and Selection of Translatable mRNA in Trypanosome Mitochondria. Pathogens. 2019;8(3).

12. Aphasizhev R, Suematsu T, Zhang L, Aphasizheva I. Constructive edge of uridylationinduced RNA degradation. RNA Biol. 2016;13(11):1078-83.

13. Schneider A. A short history of guide RNAs: The intricate path that led to the discovery of a basic biological concept. EMBO Rep. 2020;21(12):e51918.

14. Schneider A, Ochsenreiter T. Failure is not an option - mitochondrial genome segregation in trypanosomes. J Cell Sci. 2018;131(18).

15. Tumova P, Voleman L, Klingl A, Nohynkova E, Wanner G, Dolezal P. Inheritance of the reduced mitochondria of Giardia intestinalis is coupled to the flagellar maturation cycle. BMC Biol. 2021;19(1):193. 
bioRxiv preprint doi: https://doi.org/10.1101/2021.12.16.473092; this version posted December 17, 2021. The copyright holder for this preprint (which was not certified by peer review) is the author/funder, who has granted bioRxiv a license to display the preprint in perpetuity. It is made available under aCC-BY 4.0 International license.

\section{5}

16. Regoes A, Zourmpanou D, León-Avila G, Giezen Mvd, Tovar J, Hehl AB. Protein import, replication, and inheritance of a vestigial mitochondrion. J Biol Chem 2005;280:30557-63.

17. Robinson DR, Gull K. Basal body movements as a mechanism for mitochondrial genome segregation in the trypanosome cell cycle. Nature. 1991;352:731-3.

18. Ogbadoyi EO, Robinson DR, Gull K. A high-order trans-membrane structural linkage is responsible for mitochondrial genome positioning and segregation by flagellar basal bodies in trypanosomes. Mol Biol Cell. 2003;14:1769-79.

19. Zhao Z, Lindsay ME, Chowdhury AR, Robinson DR, Englund PT. p166, a link between the trypanosome mitochondrial DNA and flagellum, mediates genome segregation. EMBO J. 2008;27:143-54.

20. Hoffmann A, Käser S, Jakob M, Amodeo S, Peitsch C, Tyc J, et al. Molecular model of the mitochondrial genome segregation machinery in Trypanosoma brucei. Proc Natl Acad Sci U S A. 2018;115(8):E1809-E18.

21. Schnarwiler F, Niemann M, Doiron N, Harsman A, Kaser S, Mani J, et al. Trypanosomal TAC40 constitutes a novel subclass of mitochondrial beta-barrel proteins specialized in mitochondrial genome inheritance. Proc Natl Acad Sci U S A. 2014;111(21):7624-9.

22. Käser S, Willemin M, Schnarwiler F, Schimanski B, Poveda-Huertes D, Oeljeklaus S, et al. Biogenesis of the mitochondrial DNA inheritance machinery in the mitochondrial outer membrane of Trypanosoma brucei. PLoS Pathog. 2017;13(12):e1006808.

23. Käser S, Oeljeklaus S, Tyc J, Vaughan S, Warscheid B, Schneider A. Outer membrane protein functions as integrator of protein import and DNA inheritance in mitochondria. Proc Natl Acad Sci USA. 2016;113:E4467-75.

24. Vitali DG, Käser S, Kolb A, Dimmer KS, Schneider A, Rapaport D. Independent evolution of functionally exchangeable mitochondrial outer membrane import complexes. eLife. 2018;7:e34488.

25. Mani J, Desy S, Niemann M, Chanfon A, Oeljeklaus S, Pusnik M, et al. Mitochondrial protein import receptors in Kinetoplastids reveal convergent evolution over large phylogenetic distances. Nat Commun. 2015;6:6646.

26. Fujiki Y, Hubbard AL, Fowler S, Lazarow PB. Isolation of intracellular membranes by means of sodium carbonate treatment: application to endoplasmic reticulum. J Cell Biol. 1982;93(1):97-102.

27. Dean S, Gould MK, Dewar CE, Schnaufer AC. Single point mutations in ATP synthase compensate for mitochondrial genome loss in trypanosomes. Proc Natl Acad Sci USA 2013;110:14741-6.

28. Baudouin HCM, Pfeiffer L, Ochsenreiter T. A comparison of three approaches for the discovery of novel tripartite attachment complex proteins in Trypanosoma brucei. PLoS Negl Trop Dis. 2020;14(9):e0008568.

29. Trikin R, Doiron N, Hoffmann A, Haenni B, Jakob M, Schnaufer A, et al. TAC102 Is a Novel Component of the Mitochondrial Genome Segregation Machinery in Trypanosomes. PLoS Pathog. 2016;12(5):e1005586.

30. Gheiratmand L, Brasseur A, Zhou Q, He CY. Biochemical characterization of the bi-lobe reveals a continuous structural network linking the bi-lobe to other single-copied organelles in Trypanosoma brucei. J Biol Chem 2013;288:3489-99.

31. Munoz-Gomez SA, Bilolikar G, Wideman JG, Geiler-Samerotte K. Constructive Neutral Evolution 20 Years Later. Journal of molecular evolution. 2021;89(3):172-82.

32. Lukes J, Archibald JM, Keeling PJ, Doolittle WF, Gray MW. How a neutral evolutionary ratchet can build cellular complexity. IUBMB Life. 2011;63(7):528-37.

33. Stoltzfus A. On the possibility of constructive neutral evolution. J Mol Evol. 1999;49:169-81.

34. Harsman A, Oeljeklaus S, Wenger C, Huot JL, Warscheid B, Schneider A. The noncanonical mitochondrial inner membrane presequence translocase of trypanosomatids contains two essential rhomboid-like proteins. Nat Commun. 2016;7:13707.

35. Wirtz E, Leal S, Ochatt C, Cross GA. A tightly regulated inducible expression system for conditional gene knock-outs and dominant-negative genetics in Trypanosoma brucei. Mol Biochem Parasitol. 1999;99:89-101.

36. Oberholzer M, Morand S, Kunz S, Seebeck T. A vector series for rapid PCR-mediated Cterminal in situ tagging of Trypanosoma brucei genes. Mol Biochem Parasitol. 2006;145:117-20. 
bioRxiv preprint doi: https://doi.org/10.1101/2021.12.16.473092; this version posted December 17,2021 . The copyright holder for this preprint (which was not certified by peer review) is the author/funder, who has granted bioRxiv a license to display the preprint in perpetuity. It is made available under aCC-BY 4.0 International license.

37. Bruggisser J, Kaser S, Mani J, Schneider A. Biogenesis of a mitochondrial outer membrane protein in Trypanosoma brucei: targeting signal and dependence on an unique biogenesis factor. $\mathrm{J}$ Biol Chem. 2017;292:3400-10.

38. Sikorski RS, Hieter P. A system of shuttle vectors and yeast host strains designed for efficient manipulation of DNA in Saccharomyces cerevisiae. Genetics. 1989;122(1):19-27. 39. Meisinger C, Pfanner N, Truscott KN. Isolation of yeast mitochondria. Methods in molecular biology. 2006;313:33-9.

40. Sasse R, Gull K. Tubulin posttranslational modifications and the construction of microtubular organelles in Trypanosoma brucei. J Cell Sci. 1988;90:577-89. 


\section{7}

A p166 3' UTR RNAi

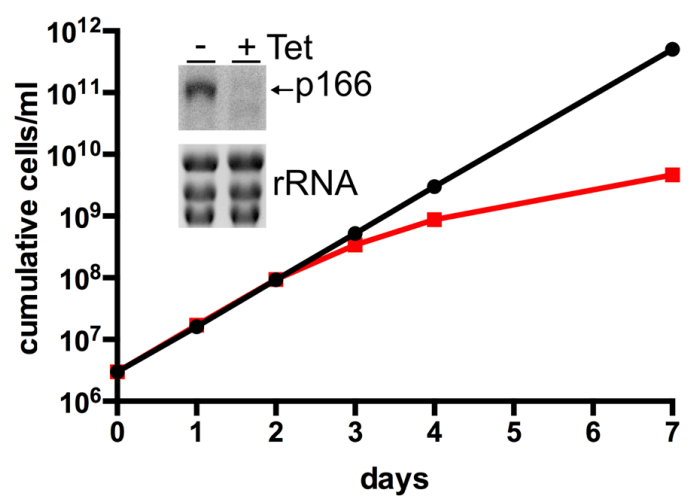

B

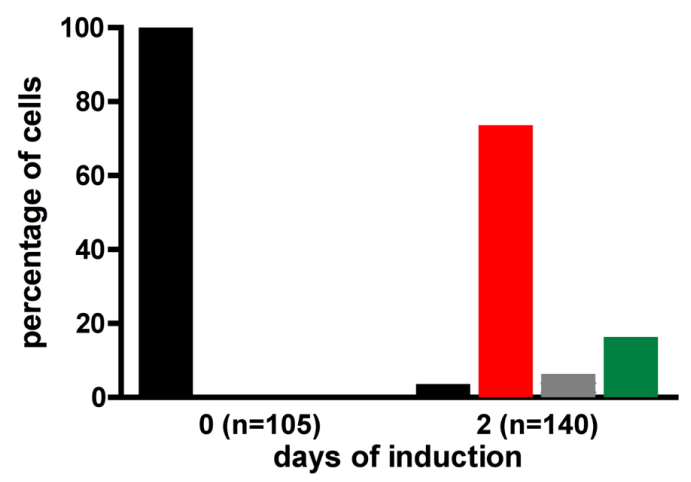

\section{p166 3' UTR RNAi \\ $+$ \\ p166-HA}
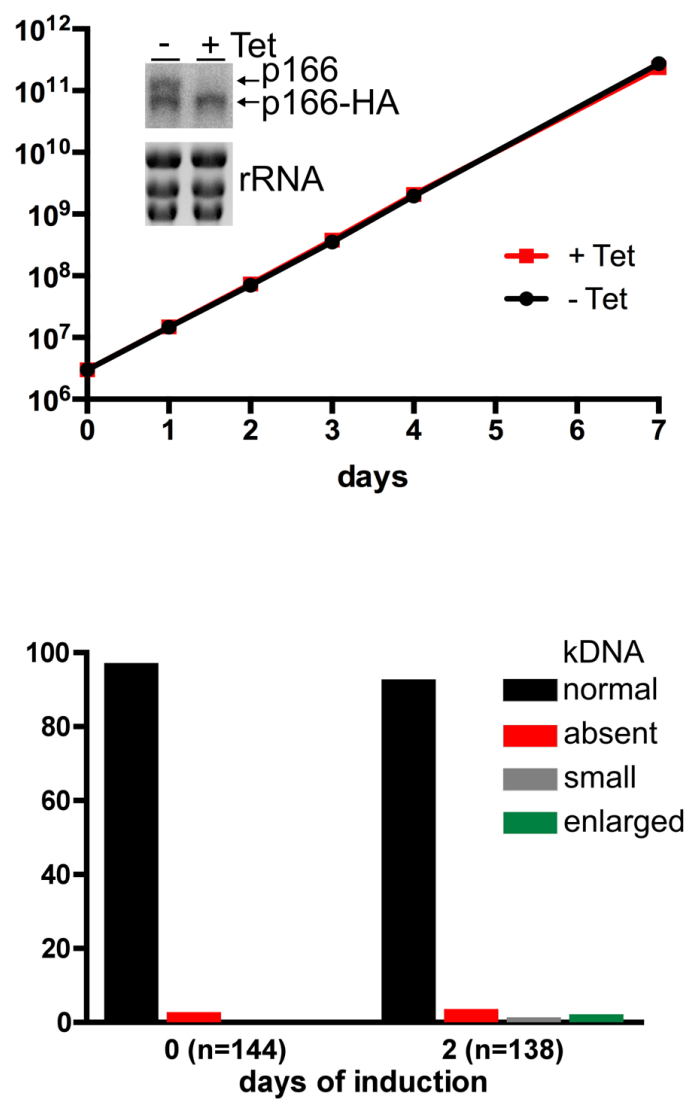
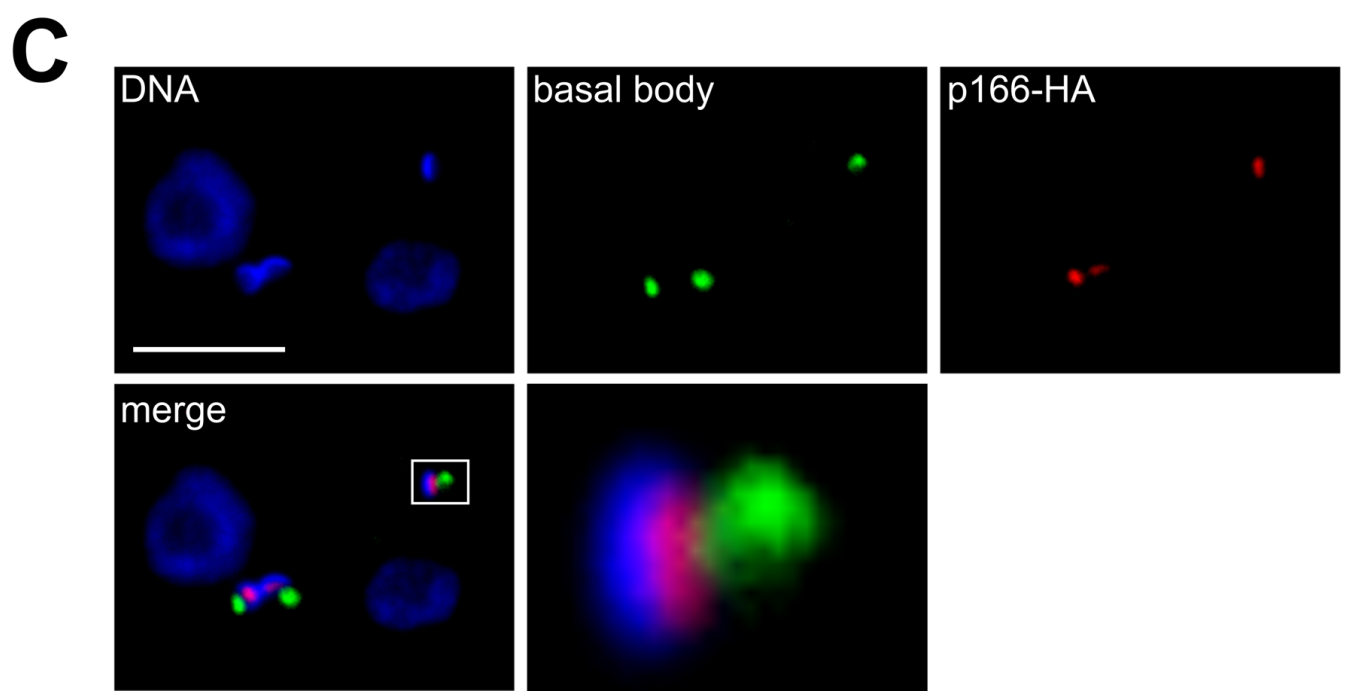

Figure 1. In situ tagged p166-HA is functional. (A) Growth analysis of cells induced for RNAi of p166 in absence (left) or presence (right) of a RNAi resistant allele encoding in situ tagged p166HA. In both growth curves inserts showing a northern blot analysis are included to demonstrate effects of tetracyclin (Tet) induced RNAi against the indicated mRNAs after 2 days of induction. Ethidiumbromide stained ribosomal RNA (rRNA) bands serve as control for equal loading. (B) DNA of uninduced (left) and RNAi induced cells (right) was stained with DAPI and kDNA content and phenotype were analyzed by fluorescence microscopy in the indicated number of individual cells. (C) Immunofluorescene microscopy with whole cells. DNA was stained with DAPI, the basal body with anti YL1/2 and tagged p166 was detected with anti-HA. The enlarged part of the merged picture is indicated by a white rectangle. The scale bar shows $5 \mu \mathrm{m}$. 
bioRxiv preprint doi: https://doi org/10.1101/2021.12.16.473092; this version posted December 17,2021 . The copyright holder for this preprint (which was not certified by peer review) is the author/funder, who has granted bioRxiv a license to display the preprint in perpetuity. It is made available under aCC-BY 4.0 International license.

\section{8}

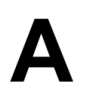

p166-HA MTS

TMD $3 \times \mathrm{HA}$

$1439-1462$
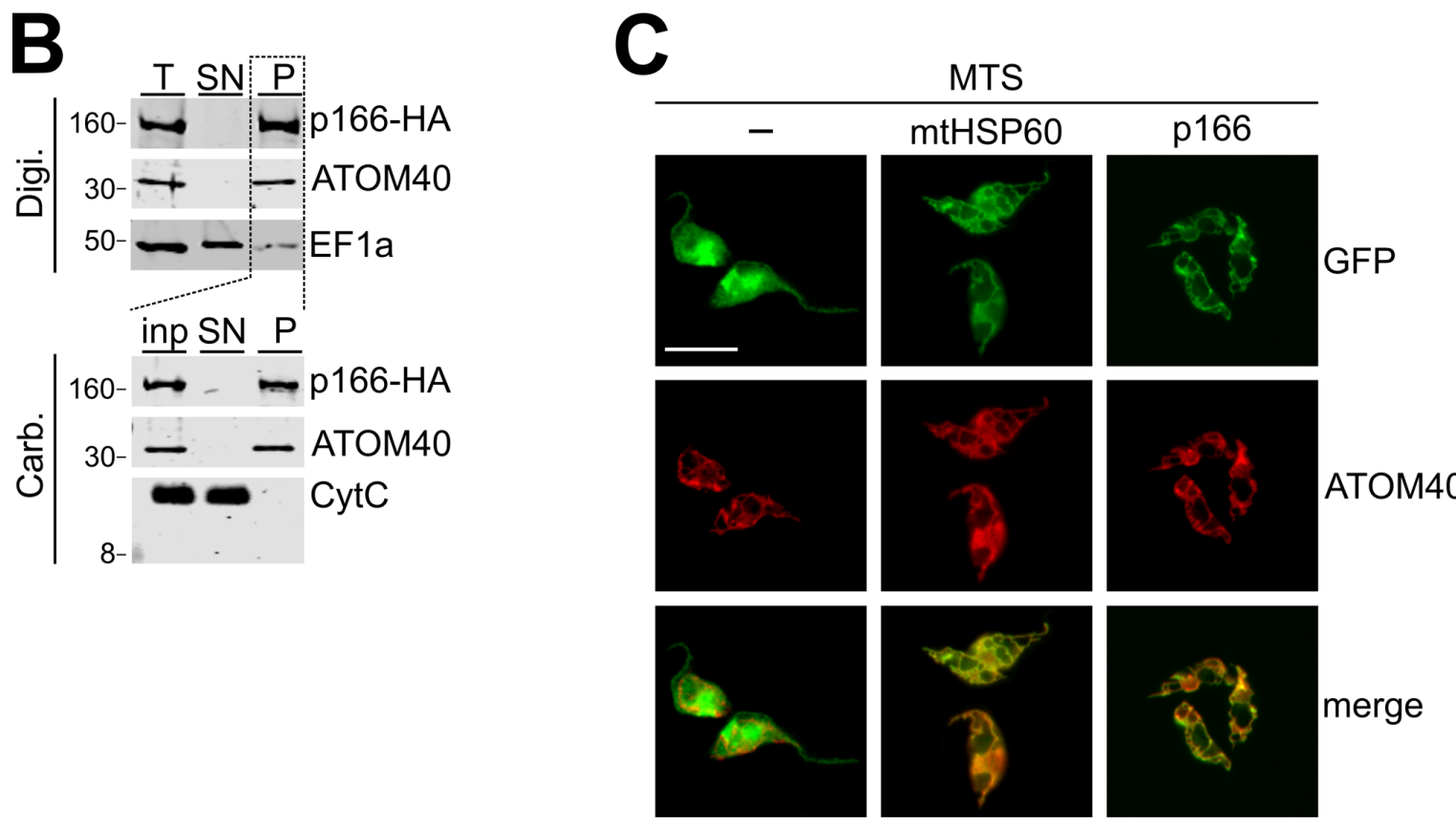

Figure 2. p166-HA is an integral membrane protein of the IM. (A) Schematic depiction (not to scale) of in situ tagged p166. A predicted mitochondrial targeting sequence (MTS) and transmembrane domain (TMD) are indicated. Numbers represent the position of amino acid residues. (B) Biochemical fractionation of cell extracts. For digitonin (Digi.) extraction same cell equivalents of total cells $(T)$, supernatant $(S N)$ and pellet $(P)$ were separated by SDS-PAGE and p166-HA, the mitochondrial outer membrane protein ATOM40 and the cytoplasmic marker EF1a were detected by immunoblot. The pellet served further as input (inp.) for alkaline carbonate (Carb.) extraction and was separated into supernatant and a final pellet. On immunoblots p166-HA, ATOM40 and the soluble protein cytochrome $\mathrm{C}(\mathrm{CytC})$ were detected. Numbers on the left indicate sizes of molecular weight marker bands in $\mathrm{kDa}$. (C) Fluorescence microscopy analysis of cells expressing variants of GFP with indicated mitochondrial targeting sequences (MTS) fused to the $\mathrm{N}$ terminus. Staining for ATOM40 serves as marker for mitochondria. 
bioRxiv preprint doi: https://doi.org/10.1101/2021.12.16.473092; this version posted December 17, 2021. The copyright holder for this preprint (which was not certified by peer review) is the author/funder, who has granted bioRxiv a license to display the preprint in perpetuity. It is made available under aCC-BY 4.0 International license.

\section{9}

A

Fig. 3

p166- $\triangle$ C-HA MTS

1467

TMD $3 \times$ HA

B

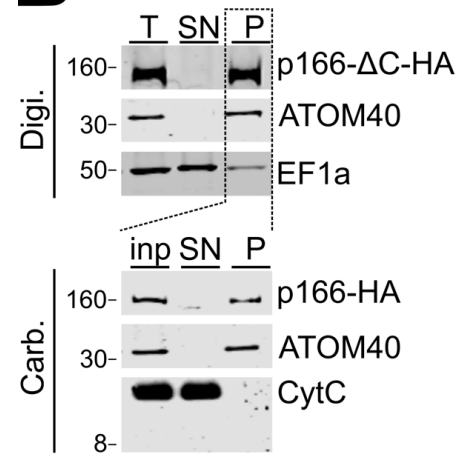
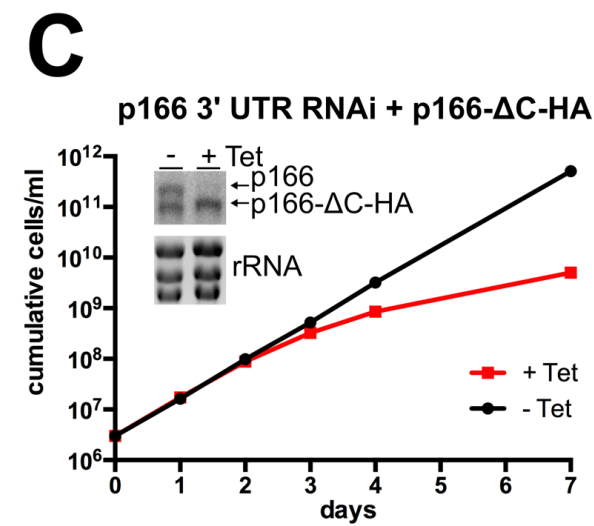

p166 3' UTR RNAi + p166- $\Delta$ C-HA
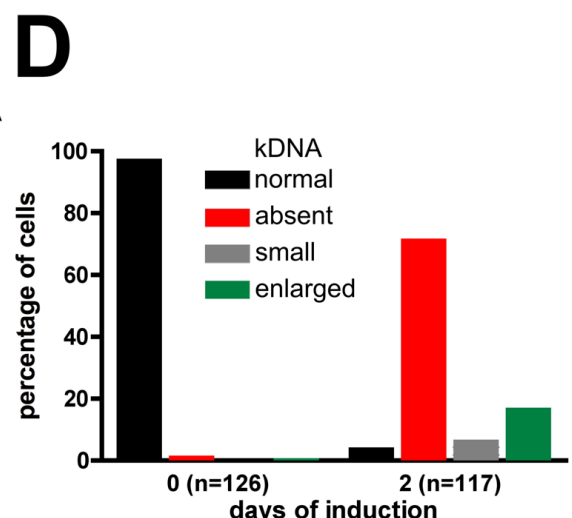

$\mathbf{E}$

-Tet

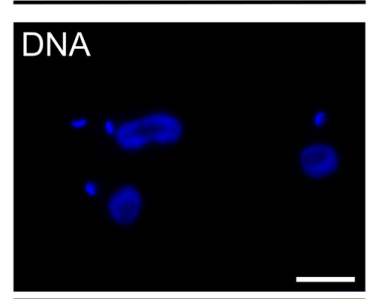

+Tet (2 days)
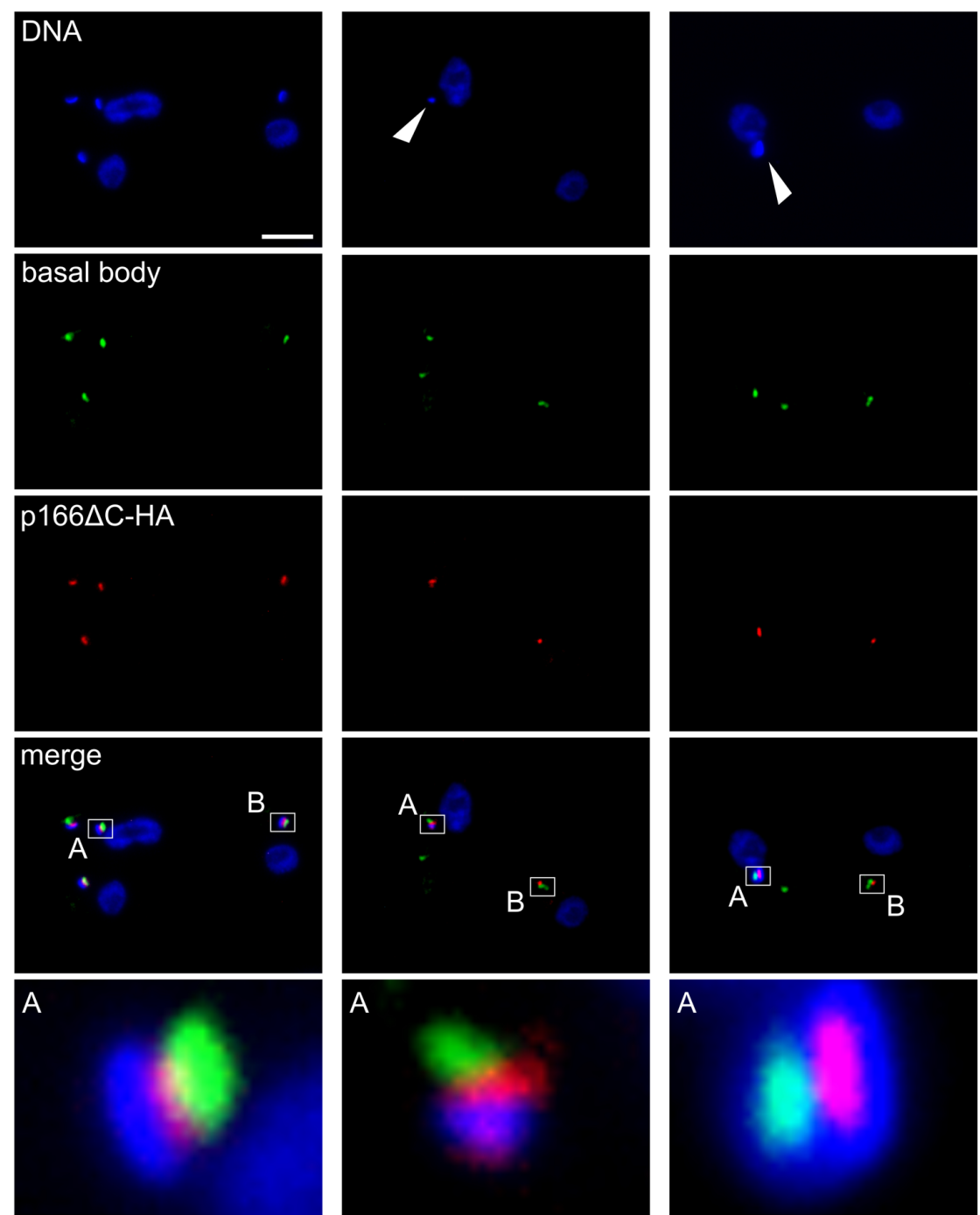

B
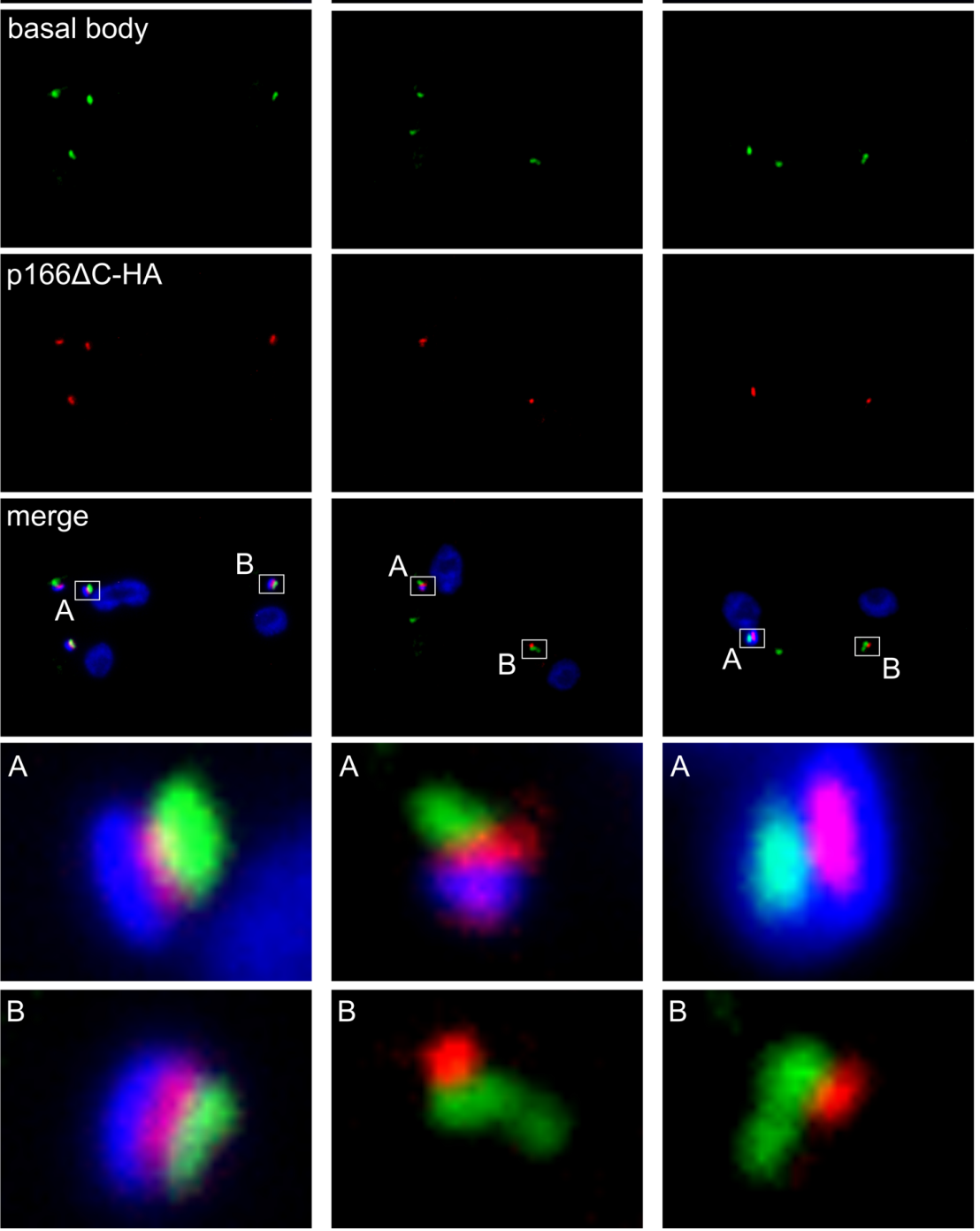
bioRxiv preprint doi: https://doi org/10.1101/2021.12.16.473092; this version posted December 17, 2021. The copyright holder for this preprint (which was not certified by peer review) is the author/funder, who has granted bioRxiv a license to display the preprint in perpetuity. It is made available under aCC-BY 4.0 International license.

$$
20
$$

Figure 3. The C-tail of $\mathbf{p} 166$ is essential for function. (A) Schematic depiction (not to scale) of in situ tagged p166 lacking the 34 amino acid C-tail (p166- $\triangle \mathrm{C}-\mathrm{HA})$. (B) Biochemical fractionation of cell extracts as described in legend 2B. (C) Growth analysis of cells uninduced (-Tet) or induced (+Tet) for RNAi against wild-type p166 with constitutive expression of p166- $\Delta \mathrm{C}-\mathrm{HA}$ as demonstrated by northern blot analysis. (D). kDNA content of cells was analyzed as described in legend 1B. (E) Whole cells left uninduced (-Tet) or being induced for 2 days (+ Tet) were analyzed by immunofluorescence microscopy for DNA (stained with DAPI), the localization of basal bodies (using anti YL1/2) and p166- $\triangle \mathrm{C}-\mathrm{HA}$. Enlarged merged pictures are shown and indicated. White arrowheads point at small kDNA (middle panel) and enlarged overreplicated kDNA (right panel). Scale bar, $5 \mu \mathrm{m}$. 
Fig. 4

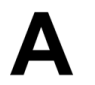

mini-p166-HA (19.6 kDa)

$\begin{array}{lll}1360 & 1501 \\ \text { MTS } & \text { TMD } & \text { 3xHA }\end{array}$

1467

$\begin{array}{cc}1360 & 1467 \\ \text { MTS } & \text { TMD } 3 \times \text { HA }\end{array}$

D

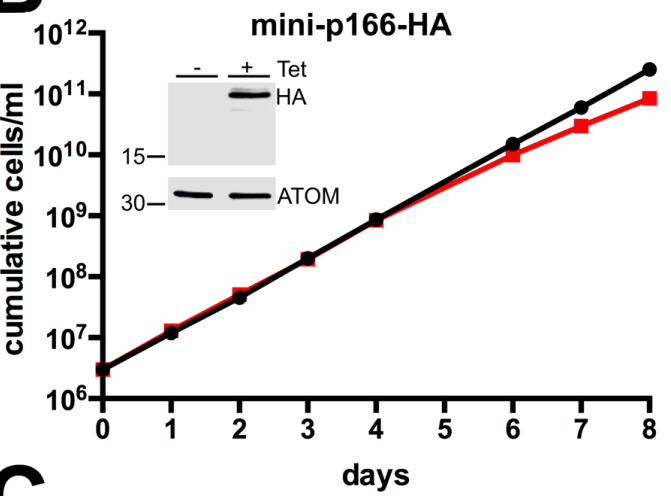

C

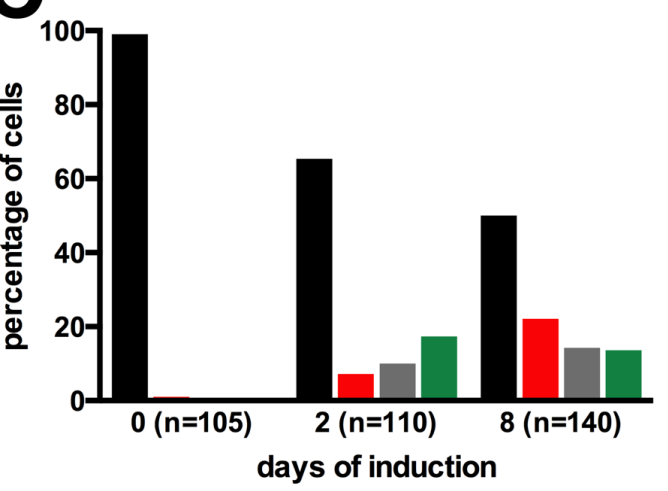

D

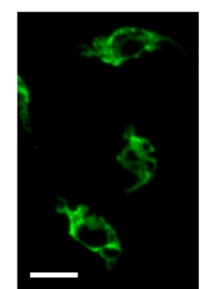

ATOM40

mini-p166-HA

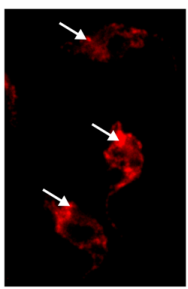

HA

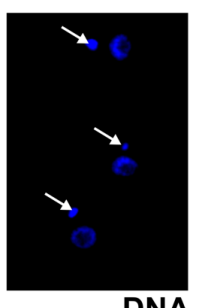

$\mathbf{E}$

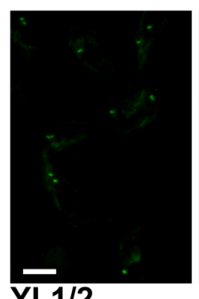

$\overline{Y L 1 / 2}$

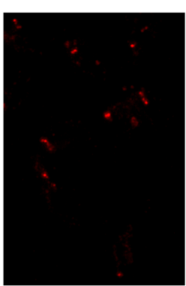

HA

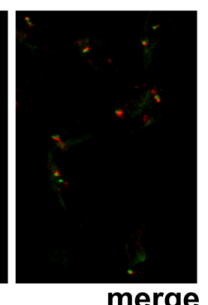

basal bodies with HA-signal: $91.8 \%(n=158)$

두

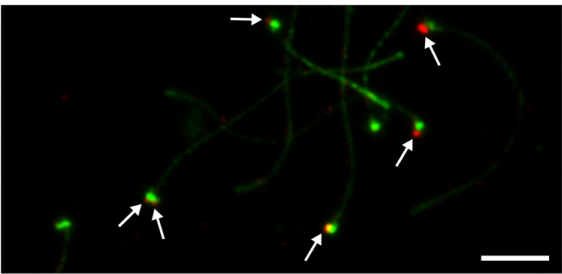

flagella with HA-signal: $47.8 \%(n=113)$
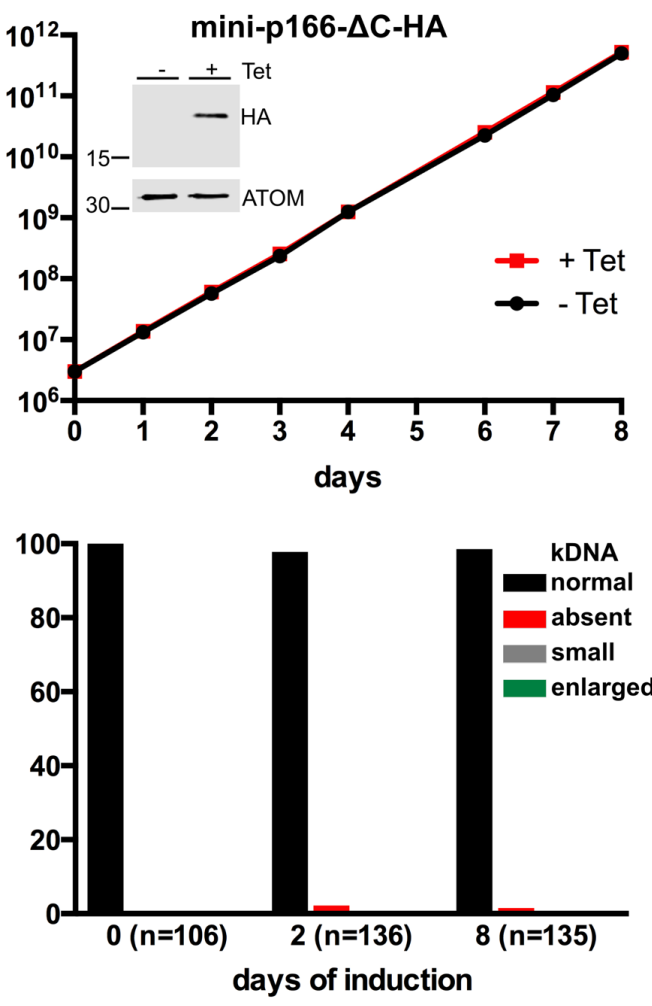

mini-p166- $\Delta$ C-HA
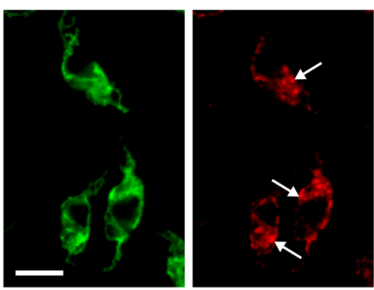

HA

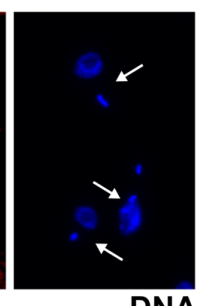

ATOM40
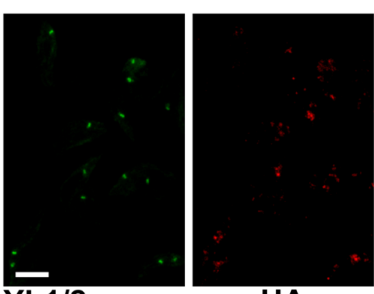

HA

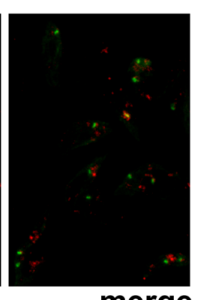

merge

$11.0 \%(n=181)$

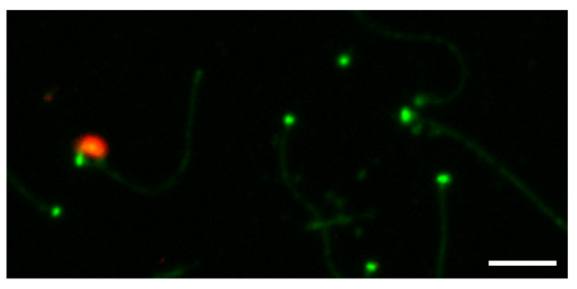

$2.8 \%(n=106)$ 
bioRxiv preprint doi: https://doi.org/10.1101/2021.12.16.473092; this version posted December 17, 2021. The copyright holder for this preprint (which was not certified by peer review) is the author/funder, who has granted bioRxiv a license to display the preprint in perpetuity. It is made available under aCC-BY 4.0 International license.

$$
22
$$

Figure 4. The C-tail of p166 is located in the intermembrane space. (A) Depiction of inducibly expressed N-terminal truncated p166 with (mini-p166-HA) or without the C-tail (mini-p166- $\Delta \mathrm{C}-\mathrm{HA}$ ) and their calculated molecular weights. Numbers indicate amino acid residue positions based on wild-type p166. (B and C) Growth analysis of untreated cells (-Tet) and cells induced for expression $(+$ Tet $)$ of the indicated proteins and subsequent analysis of kDNA content. Inducible induction is shown by immunoblots probed for HA and ATOM40 as control for equal loading. (D) Immunofluorescence microscopy of cells induced for expression of the $\mathrm{N}$-terminal truncated minip166-HA or mini-p166- $\triangle$ C-HA. anti-ATOM40 stains the mitochondrial membrane, DNA is visualized using DAPI. The arrows indicate foci with the highest signal strength derived from anti-HA. (E) Analysis of cytoskeletons for localization of basal bodies stained with anti-YL1/2 and HA-tagged mini-versions of p166. (F) Basal bodies (green) and in situ tagged truncated versions of p166-HA (red) were visualized by immunofluorescence microscopy in isolated flagella. Colocalization of both signals was analyzed in the indicated numbers of cells. Scale bar in $D, E$ and $F, 5 \mu \mathrm{m}$. 


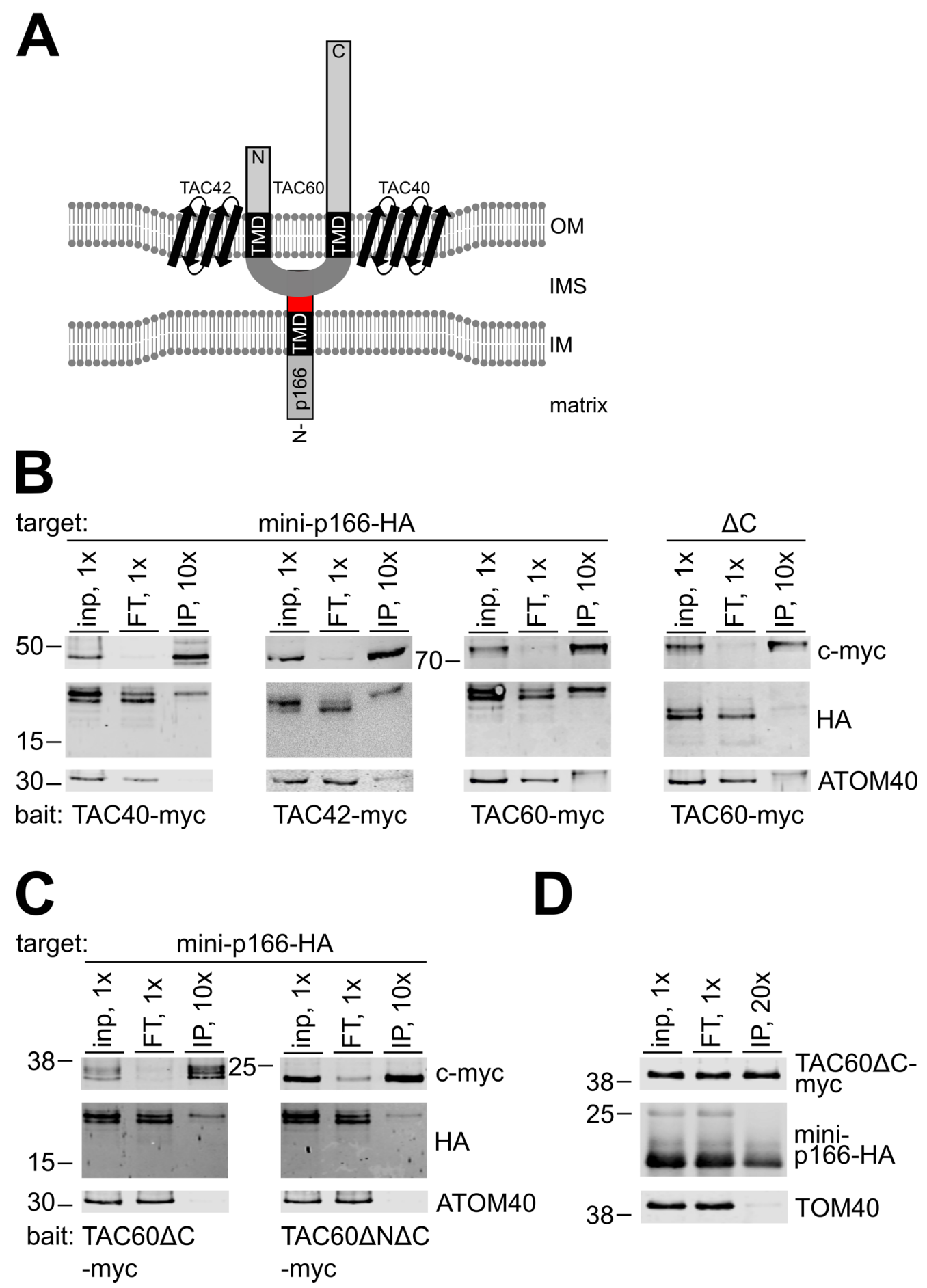

Figure 5. The $\mathrm{C}$-tail of $\mathrm{p} 166$ interacts with TAC components of the outer mitochondrial membrane. (A) Model of possible interactions. TAC60 interacts with the beta barrel proteins TAC40 and TAC42 in the outer mitochondrial membrane (OM). It contains a region between two transmembrane domains (TMD) that is located in the intermembrane space (IMS) just like the C-tail (red) of inner mitochondrial membrane (IM) anchored p166. Both the essential N-terminal domain (solid box) and the non-essential C-terminal domain (dotted box) are facing the cytoplasm. (B and C) Immunoprecipitation of indicated c-myc tagged TAC components expressed in T. brucei and analysis of copurification of $\mathrm{N}$-terminal truncated tagged versions of p166 by immunoblot and detection of the indicated antigens. (D) Immunoprecipitation of indicated proteins expressed in yeast. TOM40 serves as control for specificity. Position of molecular weight marker bands with sizes in kDa are indicated. 
bioRxiv preprint doi: https://doi.org/10.1101/2021.12.16.473092; this version posted December 17, 2021. The copyright holder for this preprint (which was not certified by peer review) is the author/funder, who has granted bioRxiv a license to display the preprint in perpetuity. It is made available under aCC-BY 4.0 International license.

\section{4}
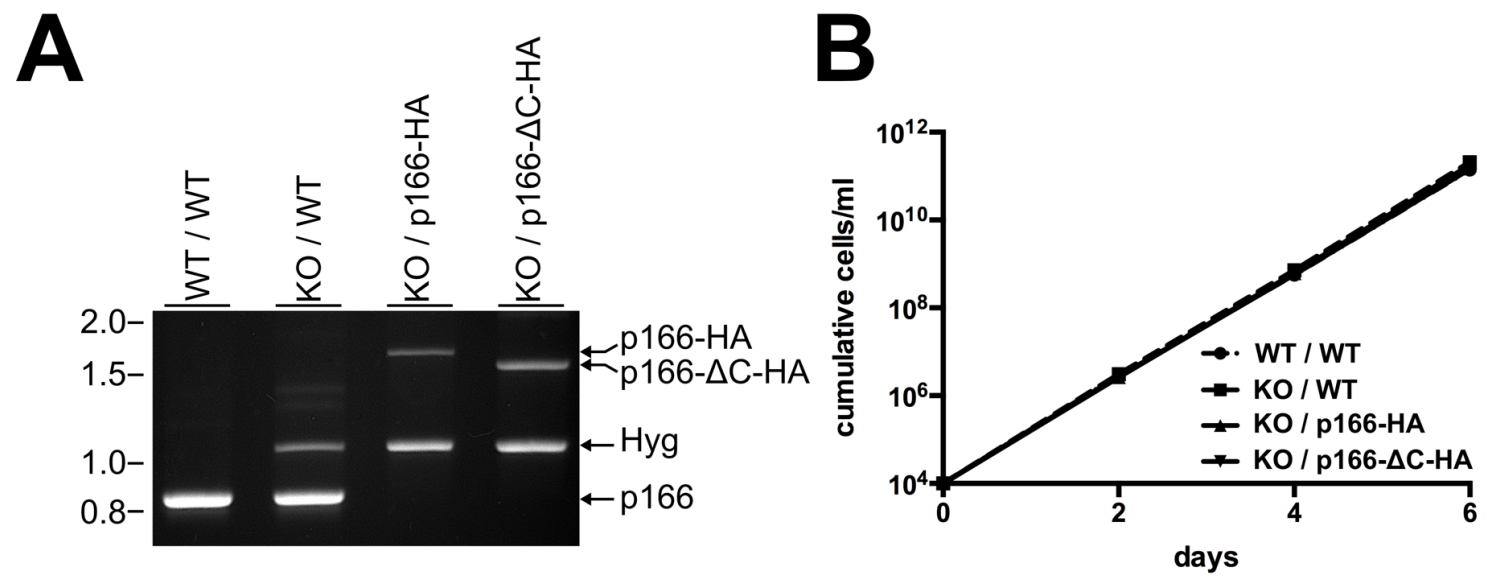

C
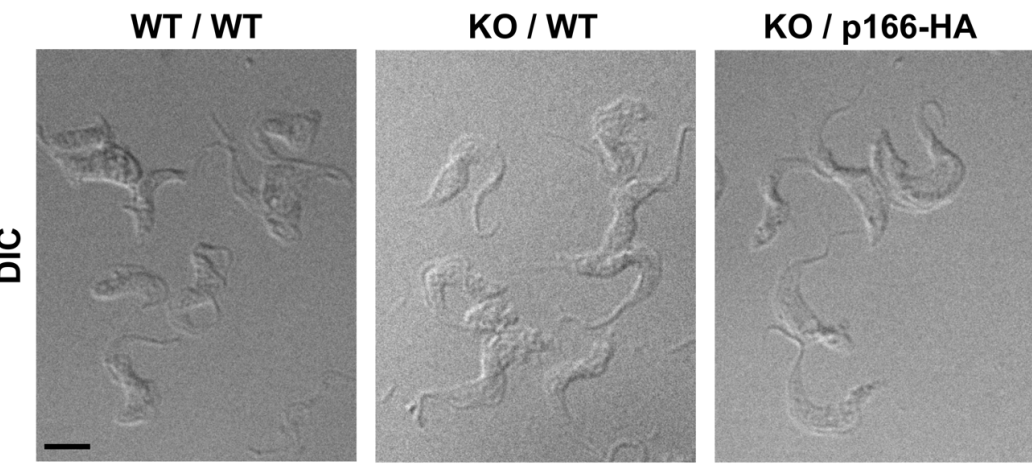

$\mathrm{KO} / \mathrm{p} 166-\Delta \mathrm{C}-\mathrm{HA}$
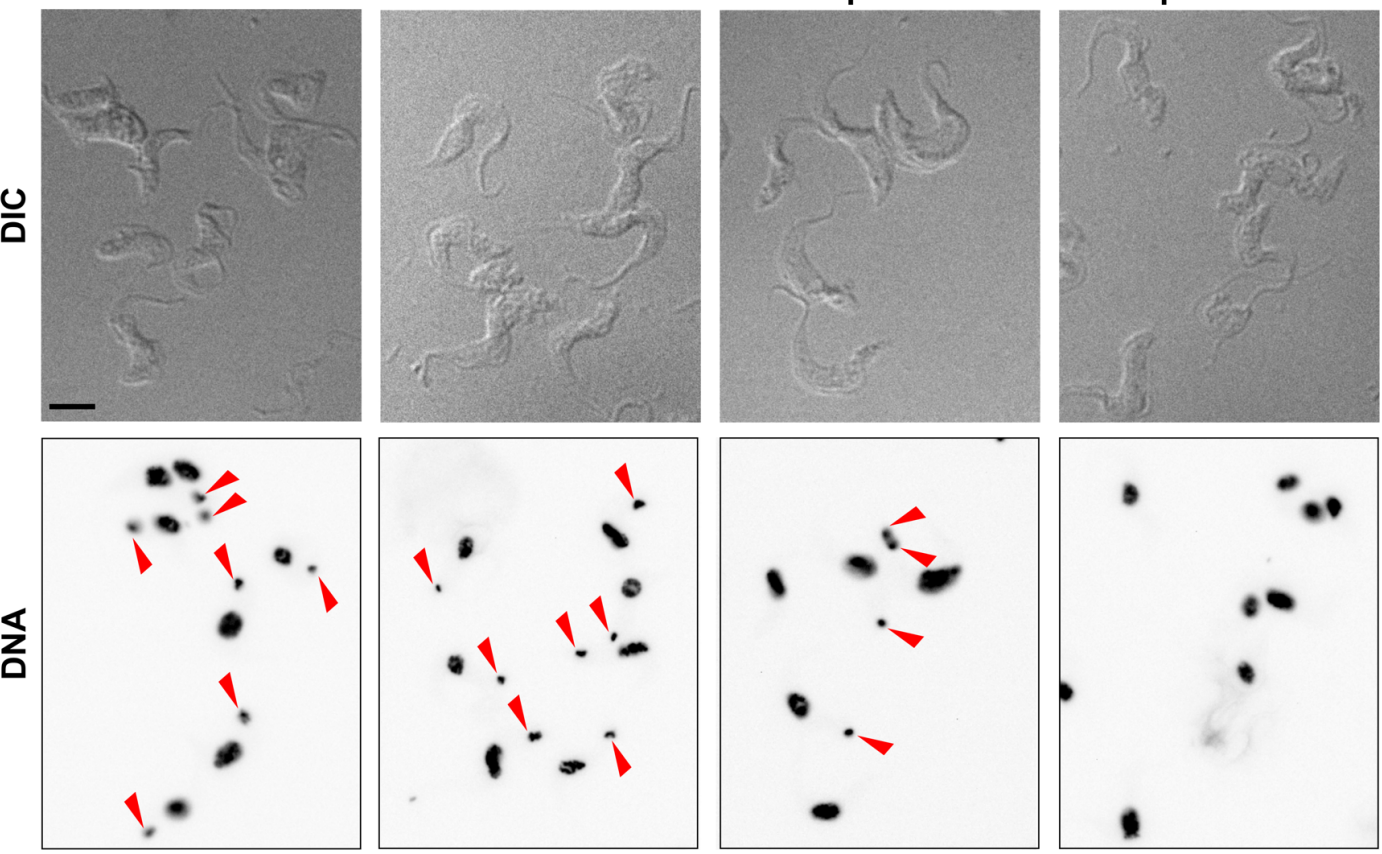

D

p166-HA

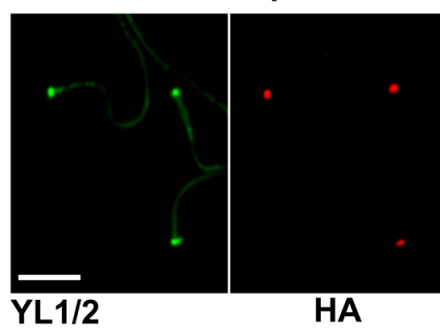

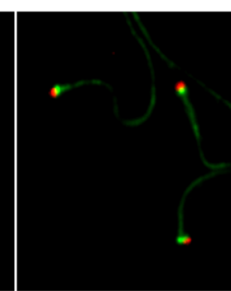

merge YL1/2 p166- $\Delta$ C-HA

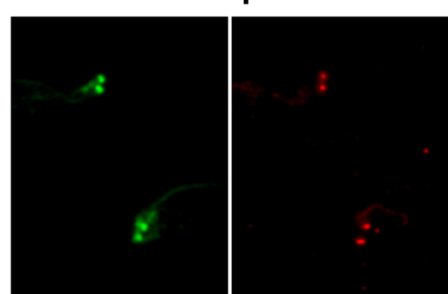

HA

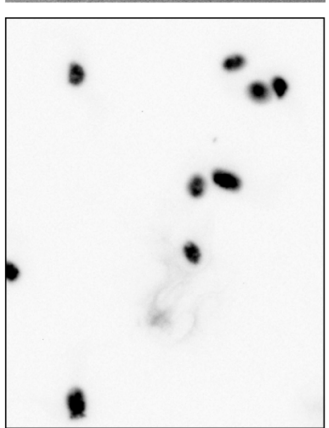

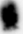

Figure 6. C-terminal truncated p166 localizes correctly. (A) Ethidiumbromide stained agarose gel after gelelectrophoresis of specific PCR products to analyze the p166 alleles of indicated cell lines. Sizes of DNA molecular weight marker bands in kb are indicated on the left. (B) Growth curve analysis of cell lines harbouring indicated alleles. (C) Fluorescence microscopic analysis of cell lines. Whole cells are visualized using DIC and nuclei and kDNA are stained with DAPI. Red arrowheads indicate the presence of kDNA. (D) Anti-HA immunofluorescene microscopy on isolated cytoskeletons to visualize the localization of full length (p166-HA) or C-terminal truncated $\mathrm{p} 166$ (p166- $\Delta \mathrm{C}-\mathrm{HA}$ ) in comparison to basal bodies stained with anti-YL1/2. Scale bars in C and D, $5 \mu \mathrm{m}$. 
bioRxiv preprint doi: https://doi.org/10.1101/2021.12.16.473092; this version posted December 17, 2021. The copyright holder for this preprint (which was not certified by peer review) is the author/funder, who has granted bioRxiv a license to display the preprint in perpetuity. It is made available under aCC-BY 4.0 International license.

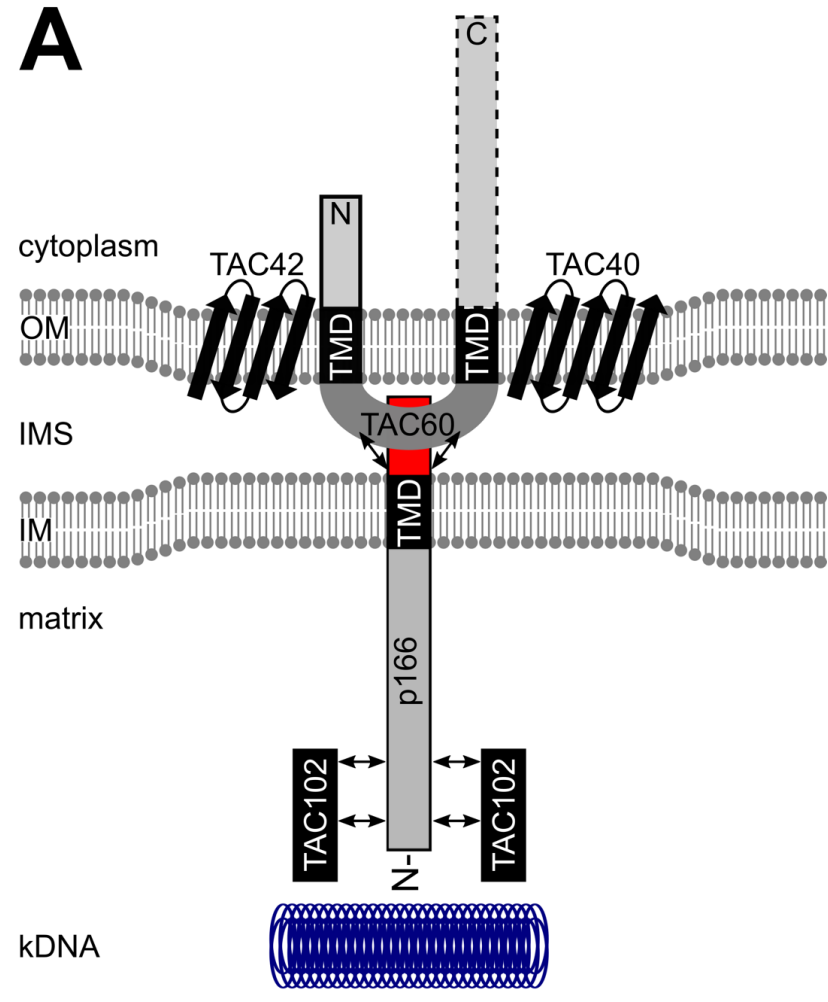

B

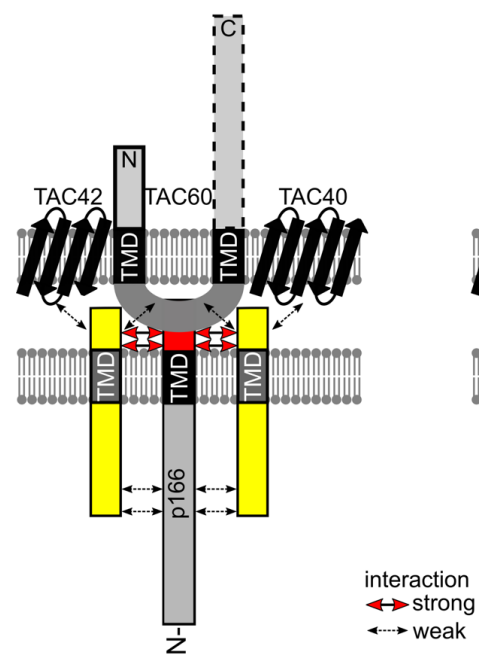

FL

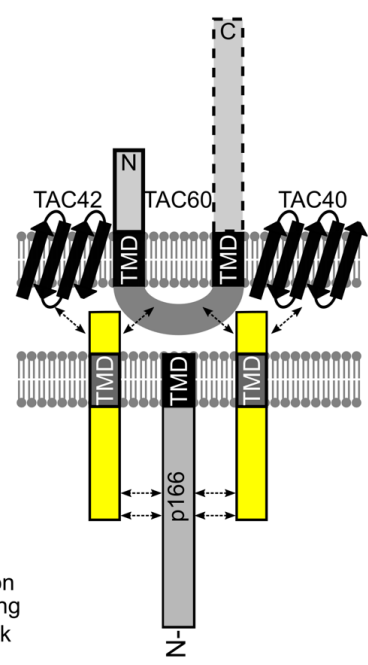

$\Delta \mathrm{C}$
Figure 7. p166 provides a bridge between OM and matrix located TAC components. (A) Model of interactions of selected TAC components. The beta barrel proteins TAC40 and TAC42 form a stable subcomplex together with TAC60 in the outer membrane (OM). The Cterminal cytoplasmic domain of TAC60 is not essential for function (indicated by a dotted box) whereas the essential $\mathrm{N}$-terminus (solid box) most likely provides the connection to cytoplasmic TAC subunits more proximal to the basal body. p166 is anchored in the inner membrane (IM) with a C-terminal transmembrane domain (TMD) exposing the short C-tail (red box) into the intermembrane space (IMS) where it interacts stably with the IMS exposed loop of TAC60. TAC102 interacts stably with the Nterminal part of $\mathrm{p} 166$ in the mitochondrial matrix and provides the connection to the kDNA disc. Protein-protein interactions are indicated by arrows. (B) Model of our working hypothesis on how non-functional C-terminally truncated p166 can be localized at the TAC. Full length (FL) p166 interacts via its intact C-tail (red box) with TAC60. So far unknown membrane anchored accessory factors (yellow) help to keep p166 in place. This is facilitated via strong interactions with the C-tail and weaker interactions with the $\mathrm{N}$-terminus and OM subunits. p166 lacking the Ctail $(\Delta C)$ can still be locked in place by the aforementioned weak interactions. However, the lack of the C-tail disables a direct strong interaction with TAC60 and leads to a loss of kDNA in daughter cells due to insufficient mechanical stability of the mutant TAC. 